\title{
Climate change and the energy performance of buildings in the future $-a$ case study for prefabricated buildings in the UK
}

Article

Accepted Version

Creative Commons: Attribution-Noncommercial-No Derivative Works 4.0

Haji Ismail, F., Shahrestani, M., Vahdati, M., Boyd, P. and Donyavi, S. (2021) Climate change and the energy performance of buildings in the future - a case study for prefabricated buildings in the UK. Journal of Building Engineering, 39. 102285. ISSN 2352-7102 doi: https://doi.org/10.1016/j.jobe.2021.102285 Available at https://centaur.reading.ac.uk/96398/

It is advisable to refer to the publisher's version if you intend to cite from the work. See Guidance on citing.

To link to this article DOI: http://dx.doi.org/10.1016/j.jobe.2021.102285

Publisher: Elsevier

All outputs in CentAUR are protected by Intellectual Property Rights law, including copyright law. Copyright and IPR is retained by the creators or other copyright holders. Terms and conditions for use of this material are defined in the End User Agreement. 


\section{www.reading.ac.uk/centaur}

\section{CentAUR}

Central Archive at the University of Reading

Reading's research outputs online 


\title{
Climate Change and the Energy Performance of Buildings in the Future -
}

\section{A case study for prefabricated buildings in the UK}

\author{
Fathin Haji Ismaila ${ }^{\mathrm{a}}$, Mehdi Shahrestani ${ }^{*}$, Maria Vahdati ${ }^{\mathrm{a}}$, Philippa Boyd ${ }^{\mathrm{a}}$, Sohrab Donyavi ${ }^{\mathrm{b}}$ \\ a: School of the Built Environment, University of Reading, \\ b: Architecture, Computing and Engineering, University of East London \\ *Corresponding author: m.shahrestani@reading.ac.uk
}

\section{Abstract:}

Climate change - partly driven by the increasing level of anthropogenic greenhouse gases - is affecting the energy consumption of buildings. This study assesses the impact of climate change on the energy performance of buildings. It focuses on the energy consumption associated with heating in a case study of prefabricated building in the UK.

The energy consumption associated with space heating is evaluated using the degree-days theory, and the actual energy consumption of the buildings is used to verify the outcome of the analytical degree-days approach for the estimated energy consumption. The verified degree-days model is then used to predict future energy demand of the case study building in 2030, 2050, and 2080 using two climate change scenarios with medium (A1B) and high (A1F1) emissions. In addition, the energy-related $\mathrm{CO}_{2}$ emissions associated with the space heating are evaluated using carbon intensity projections. This study identified the true heating base temperature for the case study building and this allows for the estimation of the future energy consumption of the building with an average $6 \%$ margin of error. For the prefabricated case study building, the energy consumption associated with heating in 2030 and 2080 is expected to be up to $12 \%$ and 34\% lower than in 2017 respectively. Moreover, the outcomes of this study showed that the standard base temperature of $15.5{ }^{\circ} \mathrm{C}$ for the degree-days method is significantly higher than the actual heating base temperature of the prefabricated building by $2.5^{\circ} \mathrm{C}$.

Keywords: climate change, energy consumption, degree-days theory, carbon dioxide emissions

\subsection{Introduction}

Climate change is one of the most pressing global issues of our time. IPCC (2014) stated that the main causes of climate change are the emissions of anthropogenic greenhouse gases $(\mathrm{GHG})$, which include carbon dioxide $\left(\mathrm{CO}_{2}\right)$, methane, and nitrous oxide. The emissions not only impact the natural systems but also have an impact on buildings and the 
built environment. Global warming (defined as the rise in the global temperature due to climate change) would lead to a reduction in the heating energy consumption of the buildings, but would also lead to an increase in the cooling energy consumption (Nik et al., 2017). Several studies identify the potential impacts of global warming on the local climate conditions in the UK (UKCP09-PROMETHEUS, 2009). The potential energy implications of climate change in the building sector have been studied previously (Zhai and Helman 2018, Nik et al., 2017). However, there are limited studies to address the impact of climate change on the energy and environmental performance of prefabricated buildings.

Prefabricated buildings are increasingly being used for new build constructions due to their capability to offer faster construction processes with lower environmental impacts. These benefits are associated with more efficient processes for developing the components of prefabricated buildings in a factory rather than those used on traditional construction sites ( $\mathrm{Li}$ et al. 2011). This study focuses on quantifying the extent to which the energy consumption associated with heating systems in the prefabricated building is influenced by climate change.

A review of the literature identified that building simulation and degree-days methods are the main approaches used to assess the energy performance of buildings under climate change. The following subsections critically review the main outcomes of previous studies that adopted these two approaches.

\subsection{Studies that adopted building simulations}

Chan (2011) conducted a series of simulations using EnergyPlus to assess the impact of climate change on buildings by modelling a case study office building and a typical residential flat. The study involved producing a set of hourly weather data under two emission scenarios, SRA1B and SRB1 (Appendix A.1) to be used for building simulation. In the next stage, a set of simulations were conducted considering the future weather projection datasets. The outcomes of the research conducted by Chan (2011) showed that under the SRA1B scenario, the energy consumption associated with the cooling system for the case study office buildings is increased by $2.6 \%, 7.8 \%$, and $14.3 \%$ respectively in 2030,2065 and 2099 compared to the reference year 1989. Under the same emission scenario, the energy consumption associated with cooling for the residential flat increased by $3.9 \%, 13.4 \%$, and $24 \%$ respectively in 2030,2065, and 2099 compared to the reference year 1989 .

Cellura et al. (2018) assessed the potential impact of climate change by investigating the trends of future energy consumption of a prototype office building in four Italian cities; 
Venice, Messina, Palermo, and Genoa. In comparison with the reference period 1979 to 1989, the outcomes of simulations conducted using TRNSYS showed an increase in the average total energy consumption mainly due to the fact that the cooling demand continues to increase and overtakes the decrease in the heating demand. In 2035, it was expected that the average total energy consumption to be increased between 17.6 to $23 \%$ under different climate change scenarios compared to the energy consumption in the typical meteorological year between 1979 and 2000.

A different building simulation tool (TAS) was used in a study conducted by Berger et al. (2014) to analyse the impact of climate change on nine case study office buildings located in Vienna, Austria. The case study buildings were categorised in terms of their age into three groups; i) built before World War 1, ii) built after World War 2 and, iii) built from 2000 onwards. Regional climate model (RCM) data were used to generate future hourly weather projections for 2050 and the period between 1961 and 1980 was set as the baseline for comparisons with future energy consumptions. The results showed that in general, the buildings face an increase in their cooling demand and a decrease in their heating demand. However, the outcomes of the study conducted by Berger et al. (2014) revealed that old buildings are more impacted by climate change compared to those built more recently. The study also suggested that cooling devices will need to meet the increasing cooling demand as a result of climate change in the future.

In another study, Shibuya and Croxford (2016) investigated the energy consumption associated with heating and cooling under climate change to explore effective measures to meet the energy demands in the future. A multi-story office as a case study building was simulated for three different locations in Japan. In addition, three different periods were selected for the simulations: 1981 to 2000, 2031 to 2050, and 2081 to 2100 . Data for these periods was generated by the Automated Meteorological Data Acquisition System (AMeDAS) of the Japan Meteorological Agency (JMA). Comparing the results of simulations for three different zones revealed that the rate of change in energy consumption is different for each region. Naha and Tokyo regions experience a continuous increase in the total energy consumption as they are in the regions where cooling is dominant. Therefore, the increase in energy consumption to provide the required level of cooling overtakes the decrease in the energy consumption associated with heating. In contrast, Sapporo, which is located in the cold region does not experience an increase in the total energy consumption as 
the increase in cooling demand is considered to be balanced with the decrease in the heating demand which results in a reasonably constant total energy consumption.

Based on the review of these previous studies that adopted the building simulation approach to evaluate the influence of climate change on the energy performance of buildings, it is found that the heating energy demand of buildings is expected to be reduced in the future.

\subsection{Studies that adopted degree-days theory}

Lee and Levermore (2010) assessed the impact of climate change on building energy consumption using the degree-days method. The study employed the Tyndall Centre data (TYN SC2.0) for South Korea which consists of monthly grid modelled climate data for the period between 2001 and 2100. The simulations generated 28 different daily weather parameters which include maximum, minimum, and average dry bulb temperature, wind speed, and solar radiation. Four emission scenarios were considered in the study; A1F1, A2, B1, and B2 (Appendix A.1). The Heating Degree-days (HDDs) and Cooling Degree-days (CDDs) were then evaluated considering the base temperature of $15.0^{\circ} \mathrm{C}$ and $18.0^{\circ} \mathrm{C}$ for the HDDs and CDDs respectively. The base temperature is the outdoor temperature above/below which the heating/cooling system would not be required to operate in order to achieve the desired indoor design temperature. The outcomes of the study conducted by Lee and Levermore (2010) showed that HDDs is decreased between $21 \%$ and $24 \%$ in the period between 1961 and 2005 in Seoul and Ulsan. During the same period, an increase between $12 \%$ and 16\% was observed in the CDDs for both locations. Moreover, between 1980 and 2099, the HDD is expected to reach a maximum reduction of $63 \%$ and the CDD is expected to increase up to $160 \%$. One of the main areas of uncertainty associated with this study was the lack of justification for the assumed base temperature which can potentially impact the reliability of the results.

The degree-days method was used by Christenson et al. (2006) to study the impact of climate change on buildings. The study was carried out in four major cities in Switzerland; Geneva, Zurich, Lugano, and Davos. They considered a set of base temperatures; 8, 10, and $12{ }^{\circ} \mathrm{C}$ for the HDD analysis. For cooling degree-days analysis, $18.3^{\circ} \mathrm{C}$ was considered as the base temperature. The outcomes showed a decrease in the HDDs between $11 \%$ and $18 \%$ through the period between 1901 and 2003. In addition, the study predicted that depending on the locations and magnitude of climate warming, the HDDs will be reduced by $13-17 \%$ in 
2085 compared to 1975 's level. In contrast, the study predicted a significant increase in the energy consumption associated with cooling, up to $2100 \%$ by 2085 compared to 1975 . This figure is likely to indicate some level of uncertainty because the assumed base temperature of $18.3^{\circ} \mathrm{C}$ might only apply to buildings with higher internal heat gains. This highlights the fact that a more accurate base temperature is needed to improve the reliability of the predicted energy consumption associated with heating and cooling using degree days theory.

Although the impact of climate change on the energy performance of buildings has been studied (Chan, 2011; Cellura et al., 2018; Berger et al.; 2014; Shibuya and Croxford, 2016; Lee and Levermore, 2010; Berger et al.; 2016, Shen et al., 2020, Hosseini et al., 2018, and Christenson et al. 2006, Bhatnagar et al., 2018 and Yau and Hasbi (2017)), the majority of the previous studies focused on traditional buildings and there are very limited studies which focus on assessing the impact of climate change on the energy performance of prefabricated buildings.

\subsection{Research aim}

According to the literature, both building simulation and degree-days methods have been used to assess the impact of climate change on the energy performance of buildings. However, the main challenge found in the previous studies which adopted the approach of building simulation was the uncertainty associated with the results. This is mainly due to the fact that building simulation requires a big set of input data, some of which is hard to assume accurately. On the other hand, the degree-day theory needs fewer inputs, one of which is the base temperature. One of the main challenges in degree-days analysis is to find the true base temperature. By addressing these methodological challenges, this study aims to assess the impact of climate change on the energy performance of buildings with a focus on energy consumption associated with heating in a prefabricated case study building in the UK. To achieve this aim there are four main objectives for this study:

- To study the relationship between the energy consumptions of buildings and outdoor thermal conditions.

- To explore different methods available to estimate the energy consumptions of buildings.

- To compare the actual energy consumption associated with the space heating with the predicted energy consumption considering the historical weather conditions (meteorological data) and future energy consumptions under different climate change scenarios. 
- To estimate the energy-related $\mathrm{CO}_{2}$ emissions associated with space heating under different emission scenarios.

This study proposed a practical approach to predict the energy consumption of buildings considering climate change and verified the proposed approach in a case study prefabricated building. Both the proposed approach and findings of this study are of great significance in allowing more realistic modelling of the effect of climate change on the future energy performance of the prefabricated buildings and their contribution to reducing the UK energy demand.

\subsection{Research design}

This study adopts the approach proposed by degree-days theory to assess the energy performance of a case study non-residential prefabricated building (Chancellors Building at the University of Reading in the UK) under different climate change scenarios. This approach was chosen because of its capability to assess the energy performance of buildings using a limited set of inputs. This is in contrast to the large number of inputs required for numerical simulations. Gathering and entering a large amount of data into simulation tools increases the complexity of the process and the reliability of results heavily depends on the levels of accuracy and uncertainties associated with these inputs (Hui, 2003). In a recent study, Hong et al. (2018) identified the main challenges associated with the building simulation including, the limitation of building simulation on addressing performance gap, capturing the interaction between human and building services, modelling the actual operation and control mechanisms, and the faults in the operation of buildings environmental services. Considering these well-established constraints associated with building simulation, degree days theory can provide more reliable results if conducted rigorously, using fewer and more accurate inputs and taking into account the actual energy demand of buildings to establish the true base temperature.

The energy demand of the buildings depends on many factors most importantly the outdoor conditions such as the outdoor temperature (Perez-Andreu et al., 2018). Degree-days theory explained the linear relationships between the weather-related energy consumptions of the buildings and outdoor dry bulb temperature (CIBSE 2006). Degree-days is referred to as the summation of temperature differences between a reference temperature (the base temperature) and an outdoor temperature over time (Carbon Trust, 2002). The heating system needs to operate only when the outdoor temperature falls below the base temperature. Similarly, cooling is needed only when the outdoor temperature rises above the base 
temperature. The base temperature is the outdoor temperature above/below which the heating/cooling system would not be required to operate in order to achieve the desired indoor design temperature. Therefore, HDDs measure the summation of the temperature differences between base temperature and outdoor temperatures that fall below the base temperature; and vice versa for CDDs which measures summation of the temperature differences between base temperature and outdoor temperatures that rise above the base temperature (CIBSE, 2006).

Although several published degree-days data are calculated considering a base temperature of $15.5^{\circ} \mathrm{C}$ as a so-called "standard base temperature", degree-days analysis will be made more reliable by establishing the true base temperature of the building first rather than relying on this standard base temperature (Carbon Trust, 2002). In some cases, the true base temperature of a building is significantly different from the standard base temperature as it depends on many factors including the thermal characteristics and specifications of the environmental systems deployed in the building (CIBSE, 2006). To briefly demonstrate the impact of base temperature on heating degree-days and considering the weather data for London Gatwick station, the total heating degree-days for the period of October 2019 to October 2020 for the standard base temperature $\left(15.5^{\circ} \mathrm{C}\right)$ was $1802(-)$ compare to $1181(-)$ for the base temperature of $13{ }^{\circ} \mathrm{C}$ (Degreedays.net, 2020). This highlights the fact that a 2.5 ${ }^{\circ} \mathrm{C}$ difference between standard and a true base temperature can potentially result in the overestimation of heating degree days and consequently energy consumption associated with heating systems by up to $50 \%$ of the actual values. In this research, the performance line method is adopted to evaluate the true base temperature (CIBSE, 2006).

This study evaluates the impact of climate change on the energy performance of a prefabricated non-domestic building. The Chancellor's Building, a prefabricated building on the Whiteknights Campus of the University of Reading was built in 2016 and includes offices, meeting rooms, and classrooms with a total useful floor area of $3473\left(\mathrm{~m}^{2}\right)$. The building is a two-story modular block and is typical of the type used for modern office accommodation. The heating systems of the building consists of electrical radiators for the offices and air-source heat pumps for classrooms. The detailed energy consumption of the building can be found on the University Sustainability website (UoR, 2020). As a first step, the actual energy consumption of the building, as well as local weather conditions collected over a period of 12 months, were used to determine the true base temperature using the performance line method. The true base temperature was then used to predict the energy 
consumption associated with space heating in the next year, and this was compared with the actual energy consumption of the system to evaluate the robustness of the process for determination of the true base temperature. Using this true base temperature, the HDDs for the standard reference period of 1961 to 1990 and HDDs for 2030, 2050, and 2080 under two climate change scenarios, medium, and high emissions, were evaluated using the UKCP09 future predicted climate data (UKCP09, 2009). These HDDs were then used to estimate the energy consumption associated with the heating process in the case study building. Energyrelated $\mathrm{CO}_{2}$ emissions were assessed considering the prediction of carbon intensity level for electricity. The rate of carbon emissions (the carbon intensity) for 2017, 2030, 2050, and 2080 used in this research based on HM Government (2009) under different scenarios which are: $70 \%$ base, $70 \%$ RES, $80 \%$ base, $80 \%$ high bio-energy, $80 \%$ resilience (low-electricity), 80\% RES, 90\% base, and 90\% RES (Appendix B.1 and B.2). It should be noted that in this study the heating degree-days are determined only for the working hours (08:00 to18:00) from January to March and from October to December when the space heating system was on according to the University's Space and Heating Policy (University of Reading, 2018). The structure of this research is provided in the research framework in Figure 1.

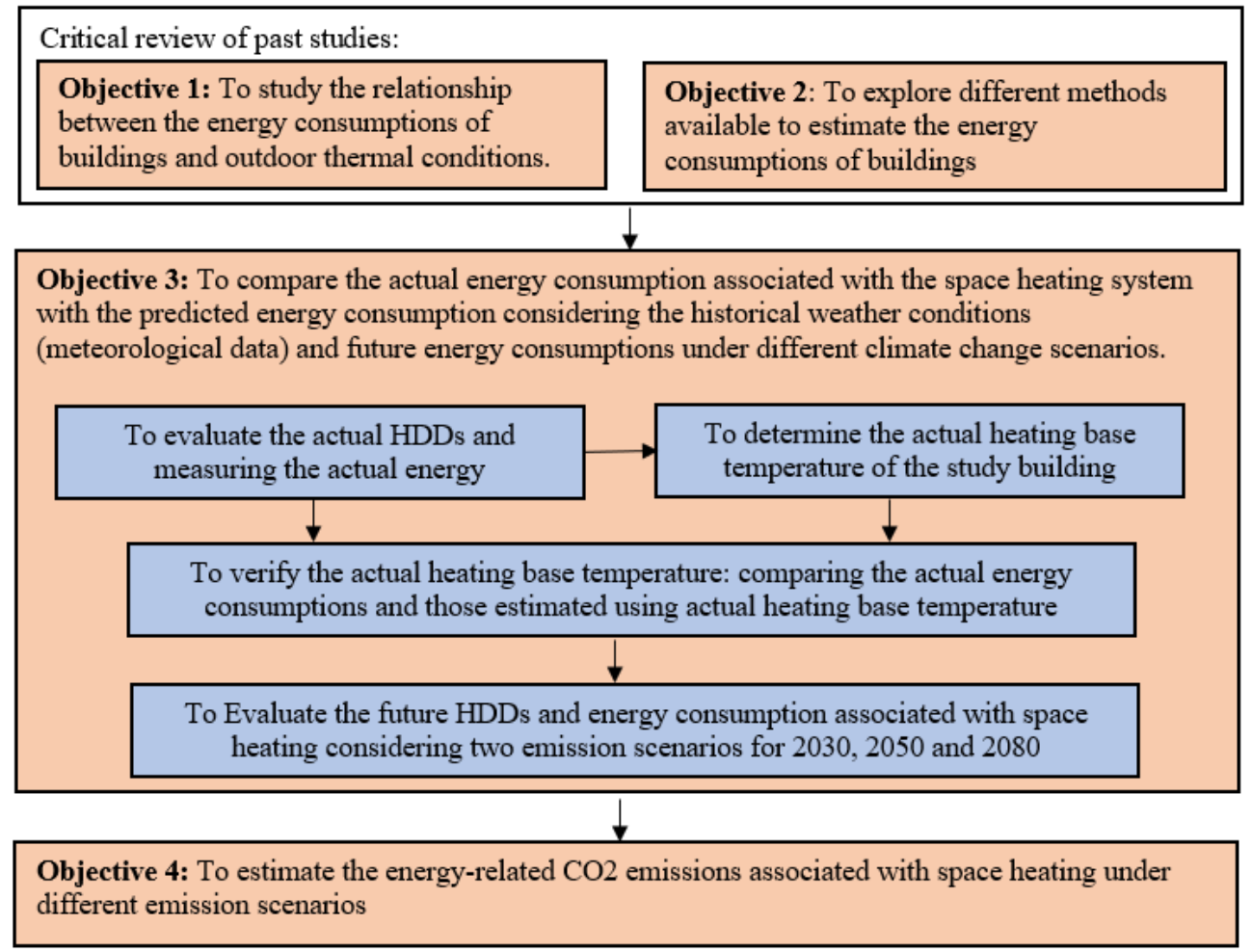

Figure 1: Research design framework 
One of the limitations of the approach taken to estimate the true base temperature was the lack of information regarding the accuracy of the actual recorded energy consumption data in the case study building. As the energy meter was part of active building services, it was not possible to set a parallel meter to check the accuracy of the existing energy meter.

\subsection{Results}

\subsection{Calculation of the true base temperature}

In order to establish the true base temperature, the performance line method is adopted in this study (CIBSE, 2006). Figure 2 shows the outcome of performance line analysis which involved fitting a best-fit second-order polynomial according to the equation (1). In this analysis, a range of base temperatures is included from 12 to $20{ }^{\circ} \mathrm{C}$, with $0.5^{\circ} \mathrm{C}$ intervals.

$$
Y=\alpha^{\prime} x^{2}+\alpha x+\beta
$$

where Y represents the daily energy consumption $(\mathrm{kWh})$, and $\mathrm{x}$ stands for the daily degreedays (-)

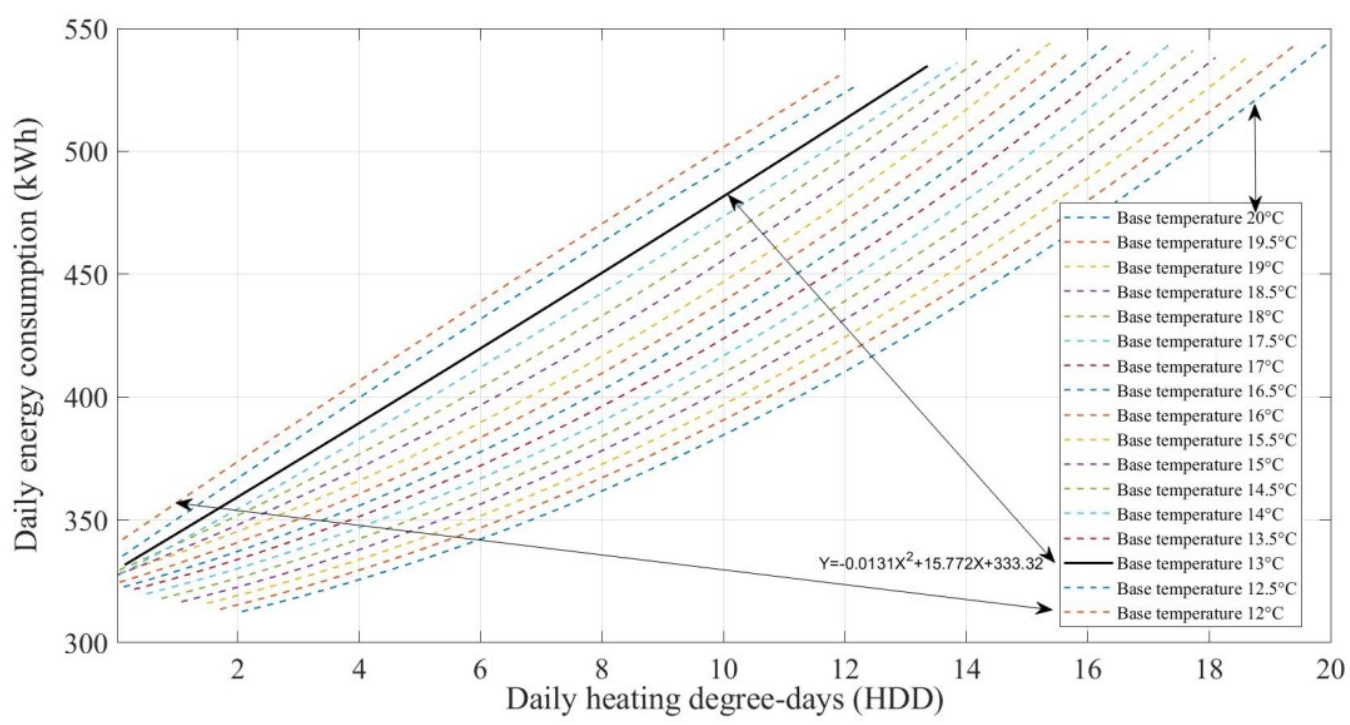

Figure 2: Results of polynomial performance lines for different base temperatures in 2017

Based on the degree-days theory, there should be a linear relationship between the HDDs developed based on the true base temperature and the weather-related energy consumption of the building. Therefore, the base temperature associated with the curve with the closest coefficient of the second-order $\left(\alpha^{\prime}\right)$ to zero (Figure 2 and Equation 1) should be 
the true base temperature of the building. For further clarity, the results of polynomial performance lines presented in Figure 2 are provided in Table 1.

As shown in Table 1, the true base temperature is between $13.0^{\circ} \mathrm{C}$ and $13.5^{\circ} \mathrm{C}$ as there is a change in the sign of $\alpha$ ' from negative to positive which implies that the line is associated with HDDs for the base temperature between $13-13.5^{\circ} \mathrm{C}$. Considering the resolution of the base temperatures used in this performance line $\left(0.5^{\circ} \mathrm{C}\right)$, this research established $13.0^{\circ} \mathrm{C}$ as the actual heating base temperature for the case study building.

Table 1: Results of polynomial performance lines, based on Figure 2

\begin{tabular}{|c|c|c|}
\hline Base Temperature $/{ }^{\circ} \mathrm{C}$ & $\alpha^{\prime}$ & $\mathrm{R}^{2}$ \\
\hline 12.0 & -0.0651 & 0.54948 \\
\hline 12.5 & -0.0841 & 0.5526 \\
\hline 13.0 & -0.0131 & 0.56774 \\
\hline 13.5 & 0.039 & 0.576 \\
\hline 14.0 & 0.108 & 0.58604 \\
\hline 14.5 & 0.2618 & 0.58312 \\
\hline 15.0 & 0.3188 & 0.58303 \\
\hline 15.5 & 0.4077 & 0.58126 \\
\hline 16.0 & 0.3935 & 0.58815 \\
\hline 16.5 & 0.4099 & 0.58861 \\
\hline 17.0 & 0.4204 & 0.58893 \\
\hline 17.5 & 0.4211 & 0.5849 \\
\hline 18.0 & 0.4168 & 0.59012 \\
\hline 18.5 & 0.4092 & 0.59081 \\
\hline 19.0 & 0.4028 & 0.59134 \\
\hline 19.5 & 0.3961 & 0.59183 \\
\hline 20.0 & 0.3905 & 0.59223 \\
\hline
\end{tabular}

\subsection{Verification of the true base temperature}

The percentage difference between the energy consumption estimated based on the determined true base temperature for the case study building and the actual energy consumption in 2018 are $6.2 \%, 3.4 \%$, and $8.1 \%$ for October, November, and December respectively (Table 2). This indicates a total difference of $5.4 \%$ between the total calculated energy consumption and actual energy consumption for the three months. As the total difference between the calculated energy consumption and the actual energy consumption is below $6 \%$, the true base temperature of $13.0^{\circ} \mathrm{C}$ is established as a reliable base temperature of this case study building. In addition, the Wilcoxon rank-sum test (Gibbons and Chakraborti, 2014) was carried out to statistically compare the calculated and actual energy consumptions. 
The outcomes of this test reveal the failure to reject the null hypothesis that data in these two datasets are samples from continuous distributions with equal medians with a high confidence interval $(\mathrm{p}=0.95)$.

Table 2: Comparisons between estimated energy consumption according to the true base temperature of $13.0^{\circ} \mathrm{C}$ and actual energy consumption for October, November, and December in 2018

\begin{tabular}{|l|c|c|c|}
\hline \multicolumn{1}{|c|}{ Month } & $\begin{array}{c}\text { Calculated energy } \\
\text { consumption (kWh) }\end{array}$ & $\begin{array}{c}\text { Actual energy } \\
\text { consumption (kWh) }\end{array}$ & $\begin{array}{c}\text { The error between actual } \\
\text { and calculated energy } \\
\text { consumption (\%) }\end{array}$ \\
\hline October & $7,834.43$ & $7,350.15$ & 6.2 \\
\hline November & $7,194.46$ & $6,949.21$ & 3.4 \\
\hline December & $3,284.21$ & $3,019.46$ & 8.1 \\
\hline Total & $\mathbf{1 8 , 3 1 3 . 1 0}$ & $\mathbf{1 7 , 3 1 8 . 8 1}$ & $\mathbf{5 . 4}$ \\
\hline
\end{tabular}

\subsection{Analysis of HDDs, energy consumption and $\mathrm{CO}_{2}$ emissions}

First, the daily HDD for the typical meteorological year between 1961 and 1990 was evaluated considering the true base temperature of the case study building. Along with the daily HDD, daily energy consumption was calculated using the best-fit second-order polynomial associated with the true base temperature. In this case, the equation is $\mathrm{Y}=$ $0.0131 x^{2}+15.772 x+333.32$ (Figure 2 ); where $Y$ represents the daily energy consumption $(\mathrm{kWh})$, and $\mathrm{x}$ stands for the daily degree-days (-). Secondly, the daily HDDs and daily energy consumption were summed to get the total HDDs and total energy consumption for the typical meteorological year between 1961 and 1990. The $\mathrm{CO}_{2}$ emissions for the standard reference period were evaluated using the carbon intensity level which is assumed as $760 \mathrm{gCO}_{2} / \mathrm{kWh}$ (Defra, 2012). The results are summarised in Table 3. The breakdown of the results on a monthly basis is presented in Appendix C.2.

Table 3: Summary of HDDs, energy consumption, and $\mathrm{CO}_{2}$ emissions for the standard reference period

\begin{tabular}{|c|c|c|c|}
\hline Year & HDDs & Energy consumption $(\mathbf{k W h})$ & $\mathbf{C O}_{2}$ emissions $(\mathbf{k g C O}$ ) \\
\hline $\begin{array}{c}\text { The typical meteorological } \\
\text { year between 1961 and 1990 }\end{array}$ & 585 & 47,175 & 35,853 \\
\hline
\end{tabular}


The heating-related energy consumption of the case study building in 2017 was assessed using the actual daily HDDs. The values for the total HDDs and total energy consumption are the summations of the daily HDDs and daily energy consumption for 2017 for the period that the heating system was in operation (between January to March and October to December). The $\mathrm{CO}_{2}$ emissions under different scenarios were then evaluated using the carbon intensity provided in Appendix B2. The results are summarised in Table 4 and the breakdown of the results on a monthly basis is available in Appendix C.1.

Table 4: Summary of actual HDD, energy consumption and $\mathrm{CO}_{2}$ emissions

\begin{tabular}{|c|c|c|c|c|c|c|c|c|c|c|}
\hline & & & \multicolumn{8}{|c|}{$\mathrm{CO}_{2}$ emissions $/ \mathrm{kgCO}_{2}$} \\
\hline$\stackrel{\dot{\Xi}}{\nu}$ & $\hat{\widehat{\hat{\Xi}}}$ & 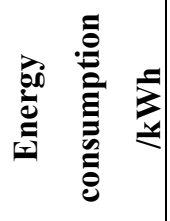 & 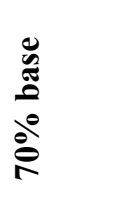 & 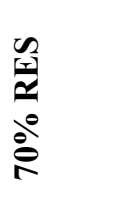 & 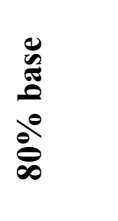 & 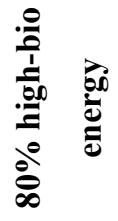 & 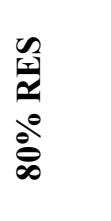 & 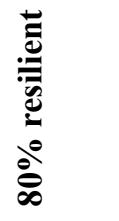 & 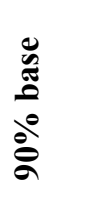 & 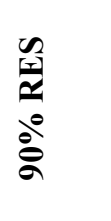 \\
\hline 2017 & 489 & 44,028 & 21,133 & 17,611 & 19,812 & 18,492 & 17,171 & 21,574 & 18,932 & 17,611 \\
\hline
\end{tabular}

Future HDDs, energy consumption, and $\mathrm{CO}_{2}$ emissions under two climate change scenarios: medium emission (A1B) and high emission (A1F1) were evaluated based on the true base temperature of $13.0^{\circ} \mathrm{C}$ and UKCP09 weather projection for 2030, 2050, and 2080. Meanwhile, the $\mathrm{CO}_{2}$ emissions under different scenarios for 2030, 2050, and 2080 were evaluated using the carbon intensity projections provided in Appendix B.2. The results are summarised in Table 5 and the monthly breakdown of the results for each year is available in Appendix $\mathrm{C} 3$ to $\mathrm{C} 8$. The summary of the heating degree- days, energy consumption for space heating, and the energy-related $\mathrm{CO}_{2}$ emissions associated with the operation of heating systems under two climate change scenarios each with five probability percentiles are presented in Table 5. For example, the annual energy consumption associated with heating systems is estimated to be $36562(\mathrm{kWh})$ in 2080 under the high emission climate change scenario with a $50 \%$ probability percentile compare to $42244(\mathrm{kWh})$ in 2030 under the same scenario. In terms of annual energy-related $\mathrm{CO}_{2}$ emissions under the above-mentioned climate change scenario, considering the $80 \%$ base carbon projection (Appendix B1), the energy-related $\mathrm{CO}_{2}$ emission is estimated to be about 2957 and $914\left(\mathrm{kgCO}_{2}\right)$ in 2030 and 2050 respectively. 
Table 5: Summary of future $\mathrm{HDD}$, annual energy consumptions and $\mathrm{CO}_{2}$ emissions

\begin{tabular}{|c|c|c|c|c|c|c|c|c|c|c|c|c|}
\hline \multirow[b]{2}{*}{$\stackrel{\grave{\Xi}}{\grave{\nu}}$} & \multirow[b]{2}{*}{ 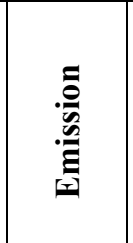 } & \multirow[b]{2}{*}{ 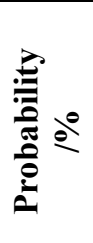 } & \multirow[b]{2}{*}{$\widehat{\widehat{\widehat{\Xi}}}$} & \multirow[b]{2}{*}{ 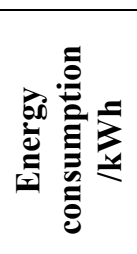 } & \multicolumn{8}{|c|}{$\mathrm{CO}_{2}$ emissions $/ \mathrm{kgCO}_{2}$} \\
\hline & & & & & 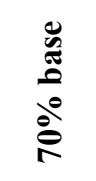 & $\begin{array}{l}\frac{0}{2} \\
\frac{0}{a} \\
\stackrel{0}{R}\end{array}$ & 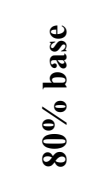 & 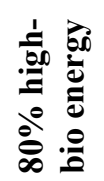 & 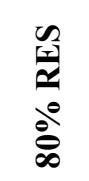 & 官: & 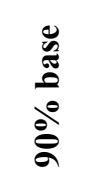 & 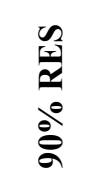 \\
\hline \multirow{5}{*}{2030} & \multirow{5}{*}{ Medium } & 10 & 536 & 43,735 & 7,872 & 6,997 & 3,061 & 4,373 & 3,498 & 9,621 & 1,093 & 1,093 \\
\hline & & 33 & 449 & 42,714 & 7,688 & 6,834 & 2,990 & 4,271 & 3,417 & 9,397 & 1,067 & 1,067 \\
\hline & & 50 & 432 & 42,447 & 7,640 & 6,791 & 2,971 & 4,244 & 3,395 & 9,338 & 1,061 & 1,061 \\
\hline & & 66 & 357 & 41,282 & 7,430 & 6,605 & 2,889 & 4,128 & 3,302 & 9,082 & 1,032 & 1,032 \\
\hline & & 90 & 276 & 38,675 & 6,961 & 6,188 & 2,707 & 3,867 & 3,094 & 8,508 & 966 & 966 \\
\hline \multirow{5}{*}{2030} & \multirow{5}{*}{ High } & 10 & 507 & 43,615 & 7,850 & 6,978 & 3,053 & 4,361 & 3,489 & 9,595 & 1,090 & 1,090 \\
\hline & & 33 & 431 & 42,770 & 7,698 & 6,843 & 2,993 & 4,277 & 3,421 & 9,409 & 1,069 & 1,069 \\
\hline & & 50 & 419 & 42,244 & 7,604 & 6,759 & 2,957 & 4,224 & 3,379 & 9,293 & 1,056 & 1,056 \\
\hline & & 66 & 428 & 42,046 & 7,568 & 6,727 & 2,943 & 4,204 & 3,363 & 9,250 & 1,051 & 1,051 \\
\hline & & 90 & 338 & 39,644 & 7,136 & 6,343 & 2,775 & 3,964 & 3,171 & 8,721 & 991 & 991 \\
\hline \multirow{5}{*}{2050} & \multirow{5}{*}{ Medium } & 10 & 488 & 43,316 & 2,165 & 1,949 & 1,082 & 1,299 & 866 & 693 & 736 & 779 \\
\hline & & 33 & 395 & 41,878 & 2,093 & 1,884 & 1,046 & 1,256 & 837 & 670 & 711 & 753 \\
\hline & & 50 & 379 & 39,957 & 1,997 & 1,798 & 998 & 1,198 & 799 & 639 & 679 & 719 \\
\hline & & 66 & 349 & 39,153 & 1,957 & 1,761 & 978 & 1,174 & 783 & 626 & 665 & 704 \\
\hline & & 90 & 233 & 35,998 & 1,799 & 1,619 & 899 & 1,079 & 719 & 575 & 611 & 647 \\
\hline \multirow{5}{*}{2050} & \multirow{5}{*}{ High } & 10 & 484 & 42,594 & 2,129 & 1,916 & 1,064 & 1,277 & 851 & 681 & 724 & 766 \\
\hline & & 33 & 406 & 41,380 & 2,069 & 1,862 & 1,034 & 1,241 & 827 & 662 & 703 & 744 \\
\hline & & 50 & 339 & 39,658 & 1,982 & 1,784 & 991 & 1,189 & 793 & 634 & 674 & 713 \\
\hline & & 66 & 307 & 38,160 & 1,908 & 1,717 & 954 & 1,144 & 763 & 610 & 648 & 686 \\
\hline & & 90 & 252 & 35,292 & 1,764 & 1,588 & 882 & 1,058 & 705 & 564 & 599 & 635 \\
\hline \multirow{5}{*}{2080} & \multirow{5}{*}{ Medium } & 10 & 470 & 42,708 & 2,135 & 1,921 & 1,067 & 1,281 & 854 & 683 & 726 & 768 \\
\hline & & 33 & 358 & 40,617 & 2,030 & 1,827 & 1,015 & 1,218 & 812 & 649 & 690 & 731 \\
\hline & & 50 & 321 & 37,049 & 1,852 & 1,667 & 926 & 1,111 & 740 & 592 & 629 & 666 \\
\hline & & 66 & 284 & 36,794 & 1,839 & 1,655 & 919 & 1,103 & 735 & 588 & 625 & 662 \\
\hline & & 90 & 192 & 32,355 & 1,617 & 1,455 & 808 & 970 & 647 & 517 & 550 & 582 \\
\hline \multirow{5}{*}{2080} & \multirow{5}{*}{ High } & 10 & 420 & 42,254 & 2,112 & 1,901 & 1,056 & 1,267 & 845 & 676 & 718 & 760 \\
\hline & & 33 & 334 & 39,577 & 1,978 & 1,780 & 989 & 1,187 & 791 & 633 & 672 & 712 \\
\hline & & 50 & 269 & 36,562 & 1,828 & 1,645 & 914 & 1,096 & 731 & 585 & 621 & 658 \\
\hline & & 66 & 234 & 35,351 & 1,767 & 1,590 & 883 & 1,060 & 707 & 565 & 600 & 636 \\
\hline & & 90 & 140 & 29,209 & 1,460 & 1,314 & 730 & 876 & 584 & 467 & 496 & 525 \\
\hline
\end{tabular}




\subsection{Discussion}

The outcomes of this study (presented in Figure 3) shows that the actual HDDs in 2017 for the Chancellors building was $16.5 \%$ lower than those calculated based on the typical meteorological year between 1961 and 1990. There is a further reduction of HDDs between $11.6 \%$ to $44.9 \%$ for the period between 2030 and 2080 compared to the actual HDDs in 2017 under both emission scenarios (medium and high). Specifically, under the medium emission scenario, there is a reduction of $11.6 \%$ in $2030,22.3 \%$ in 2050 , and $34.2 \%$ in 2080 compared to the actual HDDs in 2017. In addition, there is a reduction of $14.3 \%$ in $2030,30.6 \%$ in 2050 , and $44.9 \%$ in 2080 under the high emission scenario compared to the actual HDDs in 2017. Between the two emission scenarios, the HDDs show a higher reduction under the high emission scenario compared to the medium emission scenario. A comparison of the outcome of this study with previous research revealed that there is a higher reduction in the HDDs associated with this case study compared to those presented by Christenson et al. (2006). The study conducted by Christenson et al. (2006) only reached a maximum decrease of $17 \%$ in HDDs by 2085 , while this research predicted the maximum decrease in HDD reached $44.9 \%$ by 2080 . This outlines that there will be a higher increase in the outdoor temperature for the location of this research (Reading, UK) as compared to the increase in the outdoor temperature in Switzerland, specifically in Geneva, Zurich, Lugano, and Davos. Both analyses showed a similar descending trend for HDDs when approaching 2080 . 


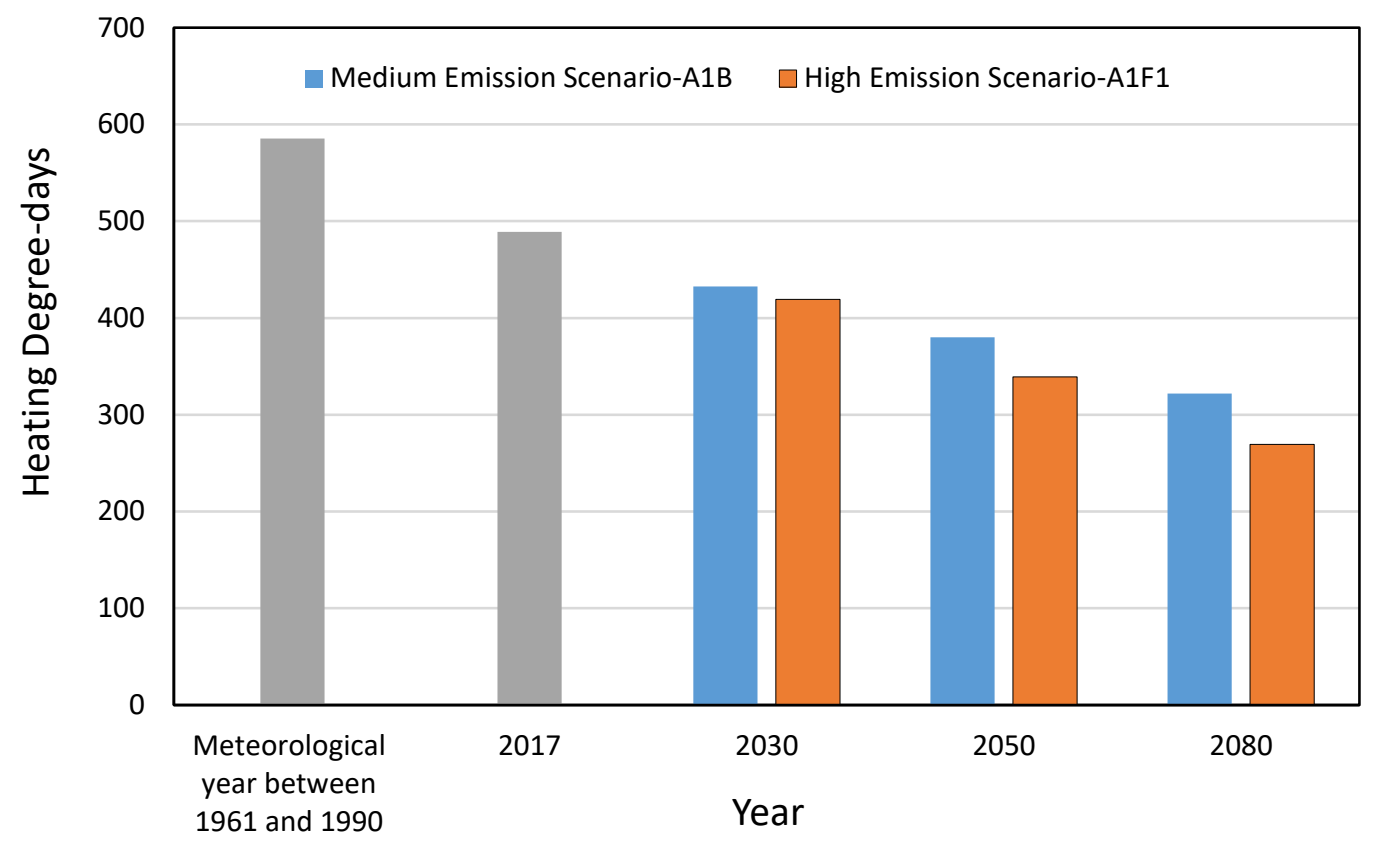

Figure 3: Comparisons between actual HDDs for 2017, HDDs for the typical meteorological year between 1961 and 1990 and predicted HDDs for 2030, 2050, and 2080 under different climate change scenarios (medium and high with the probability of 50 percentile)

The actual energy consumption associated with space heating in 2017 for the case study building is reduced by $6.7 \%$ compared to the energy consumption estimated based on the meteorological weather conditions, the period between 1961 and 1990 (Figure 4). In addition, the energy consumption associated with space heating is expected to reduce between $3.6 \%$ and $17.0 \%$ for the period between 2030 and 2080 compared to the actual energy consumptions in 2017 under both emission scenarios (medium and high). Under the medium emission scenario, the energy consumption of the building reduces by $3.6 \%$ in 2030 , $9.3 \%$ in 2050 , and $15.9 \%$ in 2080 compared to the actual energy consumption in 2017 . On the other hand, energy consumption reduces by $4.1 \%$ in $2030,9.9 \%$ in 2050 , and $17.0 \%$ in 2080 under the high emission scenario compared to the actual energy consumptions in 2017. 


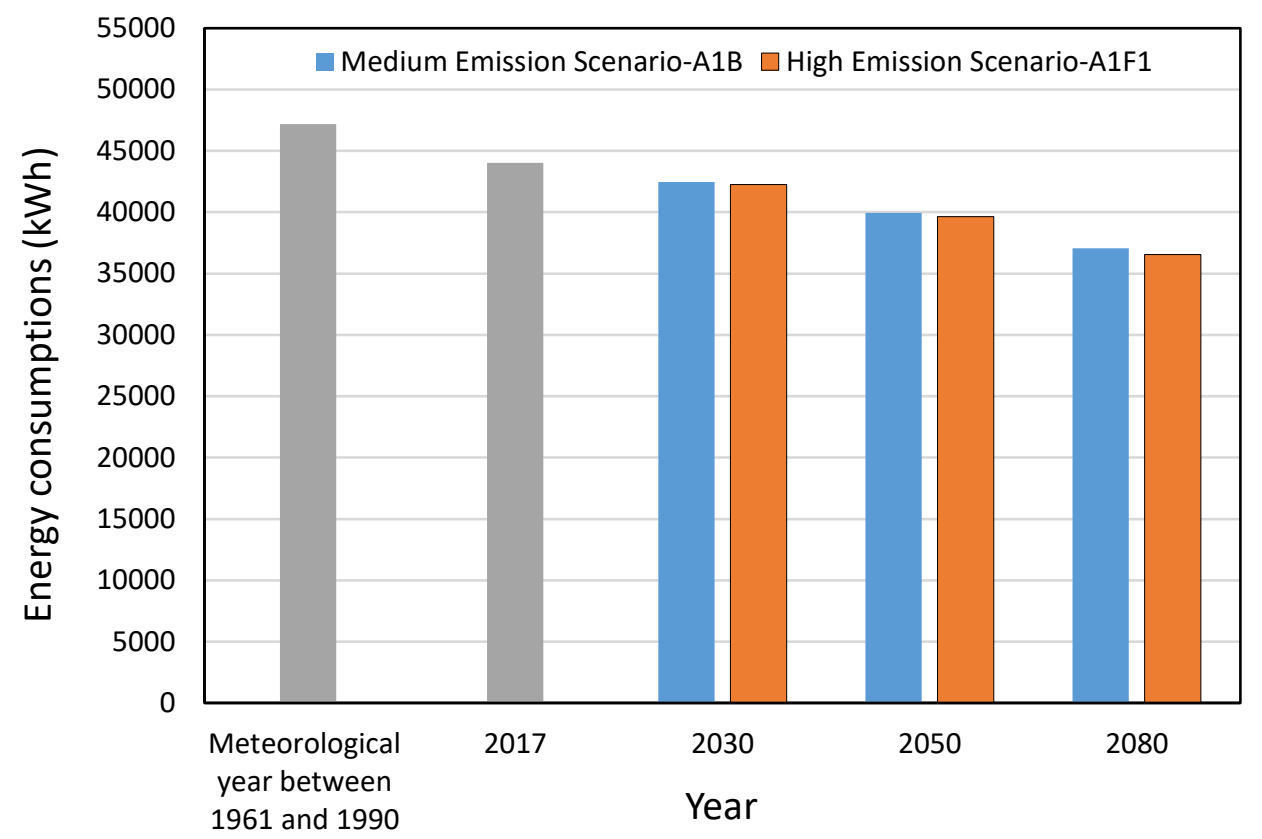

Figure 4: Comparisons between actual energy consumption associated with space heating for 2017, energy consumption for the typical meteorological year between 1961 and 1990, and the predicted energy consumption for 2030, 2050, and 2080 under different climate change scenarios (medium and high with the probability of 50 percentile).

Figure 5 shows that the actual $\mathrm{CO}_{2}$ emissions associated with space heating in 2017 for the Chancellors building is reduced by $52.1 \%$ compared to the typical meteorological year between 1961 and 1990. Moreover, there is an $80.2 \%$ and $95.7 \%$ reduction in the $\mathrm{CO}_{2}$ emissions associated with space heating respectively in 2030 and 2080 compared to the actual $\mathrm{CO}_{2}$ emissions in 2017. Under the medium emission scenario, the reduction reaches $80.2 \%$ in $2030,95.3 \%$ in 2050 , and $95.7 \%$ in 2080 compared to the actual $\mathrm{CO}_{2}$ emissions in 2017. Meanwhile, the CO2 emissions associated with the space heating in the case study building is expected to be reduced by $80.3 \%$ in $2030,95.4 \%$ in 2050 , and $95.7 \%$ in 2080 under the high emission scenario compared to the actual $\mathrm{CO}_{2}$ emissions in 2017. It should be highlighted that the outcome of the $\mathrm{CO}_{2}$ emissions analyses depends on the energy demand of the heating systems as well as the projection of carbon intensity for electricity. It should also be noted that the descending trend of the carbon intensity for electricity deriving by sustainable electricity production, plays a key role in the descending trend for $\mathrm{CO} 2$ emissions presented in this study. 


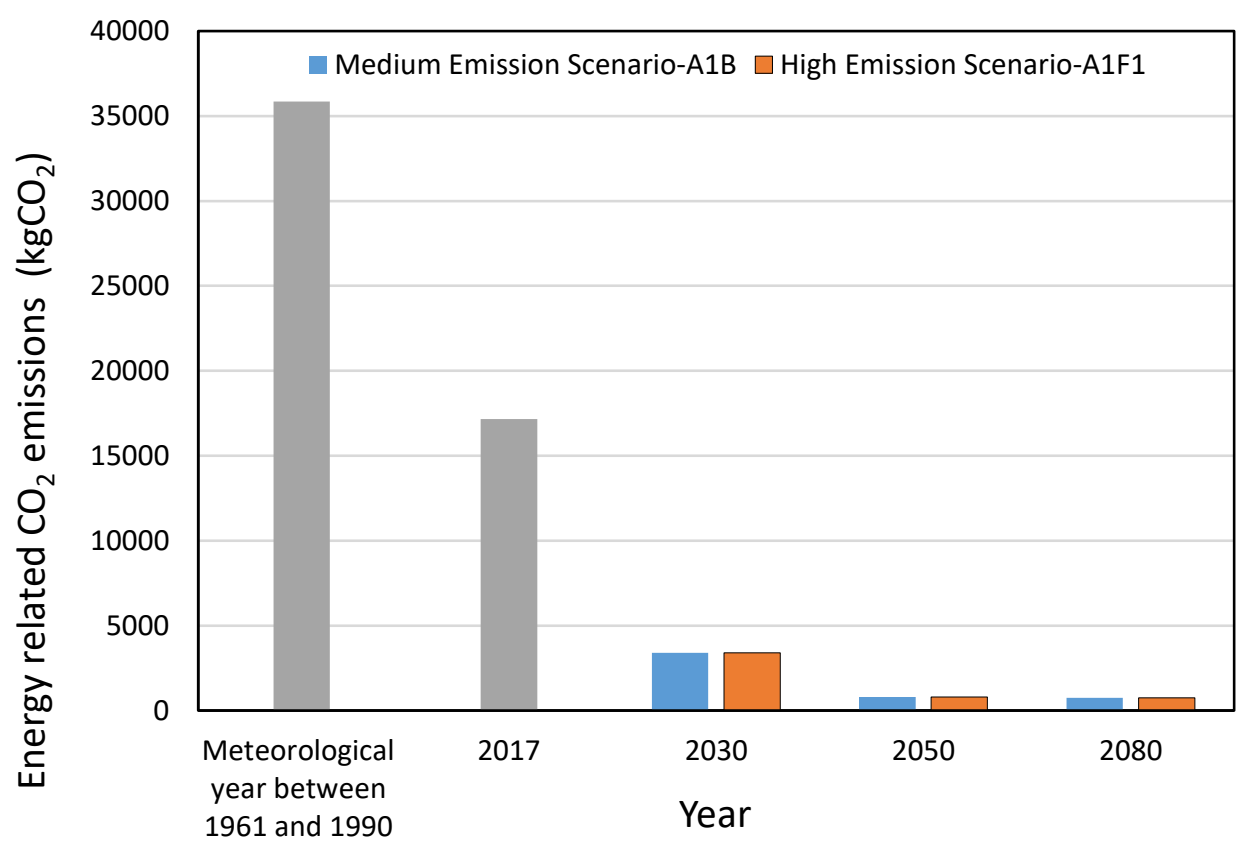

Figure 5: Comparisons between actual $\mathrm{CO}_{2}$ emissions for 2017, $\mathrm{CO}_{2}$ emissions for the typical meteorological year between 1961 and 1990, and predicted $\mathrm{CO}_{2}$ emissions for 2030, 2050, and 2080 under $80 \%$ RES scenario for different climate change scenarios (medium and high with the probability of 50 percentile)

The outcomes of this study show that the actual HDDs for 2017 are reduced by $16.5 \%$ compared to HDDs of the typical meteorological year between 1961 and 1990. This leads to a lower energy consumption associated with space heating by $6.7 \%$ in 2017 . Also, the energy consumption associated with space heating follows a descending trend with a reduction of $3.6 / 4.1 \%$ and $15.9 / 17.0 \%$ respectively in 2030 and 2080 under medium/high emission scenarios with the probability of 50 percentile compared to the actual energy consumption for 2017. In addition, this study found that the actual $\mathrm{CO}_{2}$ emissions for 2017 are significantly reduced, by $108 \%$, compared to the $\mathrm{CO}_{2}$ emissions for the typical meteorological year between 1961 and 1990. The descending trend in the energy consumption associated with heating systems as it approaches 2080, leads to a sharp drop in the level of $\mathrm{CO}_{2}$ emissions associated with space heating. Specifically, the case study building faces a $\mathrm{CO}_{2}$ emission reduction of up to $80.2 \%$ and $95.7 \%$ respectively in 2030 and 2080 , compared to the actual $\mathrm{CO}_{2}$ emissions in 2017 , under high emission scenarios with the probability of 50 percentile and considering a conservative projection of carbon intensity under $80 \%$ RES scenario. 


\subsection{Conclusions}

This research robustly quantified the influence of climate change on the energy performance of a modular prefabricated building in the UK under different climate change scenarios. It was found that the increase in GHG emissions and consequently the ambient dry bulb temperature leads to a decrease in the heating demand of buildings. In contrast with most studies in the literature, this research found that the standard base temperature $\left(15.5^{\circ} \mathrm{C}\right)$ is unlikely to represent the thermal characteristics of very well insulated prefabricated buildings. Instead, $13.0^{\circ} \mathrm{C}$ was shown to be the true heating base temperature for the case study prefabricated building. The robustness of this finding was tested using the actual energy consumption of the building. Using the true base temperature for the case study building this research was able to predict the actual energy consumption of the building with an average error of $6 \%$ in different months.

One of the challenges associated with the uptake of prefabricated buildings is the lack of reliable energy performance assessment of this type of construction, especially under weather projections for the UK. The outcome of this study revealed that the heating base temperature for the case study prefabricated building was significantly lower by $2.5^{\circ} \mathrm{C}$ than the standard heating base temperature. This lower base temperature for prefabricated case study building indicates that the energy efficiency of the prefabricated buildings is likely to exceed that of the traditionally built buildings. An improved ability to model energy usage in modular, prefabricated buildings, together with the advantages of prefabricated construction in terms of increased material efficiency, speed of construction, and reduction in required skilled manpower would cement the important place that this type of construction has in designing the future built environment. Despite the advantages of prefabricated buildings, there are concerns over the level of thermal comfort that can be offered by this type of building. Therefore, more study is needed to assess the level of thermal comfort that can be offered by highly insulated prefabricated buildings with a special focus on the investigation of the overheating risks in the prefabricated building.

\section{Acknowledgments}

The authors would like to acknowledge the support received from the Sustainability Services team at the University of Reading, especially, Dan Fernbank and Jo Burton for providing us with the required Energy Data. 


\section{References}

Berger, T., Amann, C., Formayer, H., Korjenic, A., Pospischal, B., Neururer, C. and Smutny, R. (2014) Impacts of climate change upon cooling and heating energy demand of office buildings in Vienna, Austria. Energy and Buildings, 80, 517-530.

Berger, T., Amann, C., Formayer, H., Korjenic, A., Pospichal, B., Neururer, C. \& Smutny, R. (2016). Impacts of external insulation and reduced internal heat loads upon energy demand of offices in the context of climate change in Vienna, Austria. Journal of Building Engineering, $5,86-95$.

Bhatnagar, M., Mathur, J. and Garg, V. (2018) Determining base temperature for heating and cooling degree-days for India. Journal of Building Engineering, 18, 270-280.

Carbon Trust. (2002) Degree days for energy management - a practical introduction. United Kingdom. Chartered Institution of Building Services Engineers.

Cellura, M., Guarino, F., Longo, S. and Tumminia, G. (2018) Climate change and the building sector: Modelling and energy implications to an office building in southern Europe. Energy for Sustainable Development, 45, 46-65.

Chan, A. (2011) Developing future hourly weather files for studying the impact of climate change on building energy performance in Hong Kong. Energy and Buildings, 43(10), 28602868 .

Christenson, M., Manz, H. and Gyalistras, D. (2006) Climate warming impact on degree-days and building energy demand in Switzerland. Energy Conversion and Management, 47(6), 671-686.

CIBSE. (2006) Degree-days: theory and application TM41:2006. London: Chartered Institution of Building Services Engineers.

Defra. (2012) 2012 Guidelines to Defra / DECC's GHG Conversion Factors for Company Reporting: Methodology Paper for Emission Factors. London: Crown.

Degreedays.net. (2020). Heating Degree days data [www.degreedays.net, Accessed: 25 October 2020].

Gibbons, J. D. \& Chakraborti, S. (2014). Nonparametric Statistical Inference, Fourth Edition, Revised and Expanded. 4th ed. ed. Hoboken: Taylor and Francis.

HM Government. (2009) The UK Low Carbon Transition Plan. Government of the United Kingdom.

Hong, T., Langevin, J. \& Sun, K. (2018). Building simulation: Ten challenges. Building Simulation, 11 (5), 871-898.

Hosseini, M., Tardy, F. \& Lee, B. (2018). Cooling and heating energy performance of a building with a variety of roof designs; the effects of future weather data in a cold climate. Journal of Building Engineering, 17, 107-114.

Hui, S. (2003) Effective use of building energy simulation for enhancing building energy codes. In: Proc. of the IBPSA Building Simulation 2003 Conference. Eindhoven.

IPCC. (2014) Climate Change 2014: Synthesis Report. Contribution of Working Groups I, II and III to the Fifth Assessment Report of the Intergovernmental Panel on Climate Change. 
Lee, K. and Levermore, G. (2010) Weather data for future climate change for South Korean building design: analysis for trends. Architectural Science Review, 53(2), 157-171.

Li, H., Guo, H.L., Skitmore, M., Huang, T., Chan, K.Y.N. and Chan, G. (2011). Rethinking prefabricated construction management using the VP-based IKEA model in Hong Kong. Construction Management and Economics, 29(3), 233-245.

Nik, V., Coccolo, S., Kämpf, J. and Scartezzini, J. (2017) Investigating the importance of future climate typology on estimating the energy performance of buildings in the EPFL campus. Energy Procedia, 122, 1087-1092. IPCC, Geneva, Switzerland.

Pérez-Andreu, V., Aparicio-Fernández, C., Martínez-Ibernón, A. and Vivancos, J. (2018) Impact of climate change on heating and cooling energy demand in a residential building in a Mediterranean climate. Energy, 165, 63-74.

Shen, J., Copertaro, B., Sangelantoni, L., Zhang, X., Suo, H. \& Guan, X. (2020). An earlystage analysis of climate-adaptive designs for multi-family buildings under future climate scenario: Case studies in Rome, Italy and Stockholm, Sweden. Journal of Building Engineering, 27, 100972.

Shibuya, T. and Croxford, B. (2016) The effect of climate change on office building energy consumption in Japan. Energy and Buildings, 117, 149-159

University of Reading. (2016) Chancellor's Building to provide temporary teaching spaceUniversity of Reading. [Online] Available at:

https://www.reading.ac.uk/internal/staffportal/news/articles/spsn-676029.aspx [Accessed on 11th October 2018].

University of Reading. (2018) Space Heating \& Cooling Policy. [Online] Available at: https://www.reading.ac.uk/web/files/buildingmaintenance/Space_Heating_and_Cooling_Poli cy.pdf [Accessed on 11th October 2018].

UoR. (2020). Energy consumption for the Chancellors Building [https://sites.reading.ac.uk/sustainability/energy/data/whiteknights/chancellors-building/, Accessed: 25 October 2020].

UKCP09-PROMETHEUS. (2009). Current and future weather files for the UK URL:

http://emps.exeter.ac.uk/research/energy-environment/cee/projects/prometheus/downloads/, Retrieved [Jan, 17, 2020].

Yau, Y. and Hasbi, S. (2017) A Comprehensive Case Study of Climate Change Impacts on the Cooling Load in an Air-Conditioned Office Building in Malaysia. Energy Procedia, 143, 295-300.

Zhai, Z. and Helman, J. (2018) Implications of climate changes to building energy and design. Sustainable Cities and Society, 44, 511-519. 


\section{Appendices}

\section{Appendix A: IPCC emission scenarios}

Appendix A.1: Descriptions of different IPCC emission scenarios (IPCC, 2018a)

\begin{tabular}{|c|c|}
\hline $\begin{array}{l}\text { Emission } \\
\text { Scenarios }\end{array}$ & Descriptions \\
\hline A1B & $\begin{array}{l}\text { - Rapid economic growth. } \\
\text { - Maximum population growth in the mid-century then declines } \\
\text { afterwards. } \\
\text { - Development of new and efficient technologies which is fossil intensive. } \\
\text { (balance between different sources). } \\
\text { - A group under A1 emission scenario whose technology is fossil } \\
\text { intensive. }\end{array}$ \\
\hline $\mathrm{A} 2$ & $\begin{array}{l}\text { - Extreme heterogeneous world. } \\
\text { - Self-reliance and preservation of local identities. } \\
\text { - Fertility patterns converge slowly across regions, which increased } \\
\text { - } \text { population growth. } \\
\text { - More fragmented and slow economic growth and technological change. }\end{array}$ \\
\hline B1 & $\begin{array}{l}\text { - The convergent world with peaks population in the mid-century then } \\
\text { declines afterwards. } \\
\text { - Rapid economic growth towards a service and information century. } \\
\text { - } \text { Material intensity reduced. } \\
\text { - Introduction of clean and resource-efficient technology. } \\
\text { Improved equity without additional climate initiatives to improve } \\
\text { economic social and environmental sustainability. }\end{array}$ \\
\hline B2 & $\begin{array}{l}\text { - Focus on economic, social and environmental sustainability. } \\
\text { - Continuous increase in population at a lower rate than A2. } \\
\text { - Less rapid technological development, but more diverse than A1 and B1. } \\
\text { - Oriented towards local and regional environmental protection and social } \\
\text { equity. } \\
\text { - Intermediate economic growth phase. }\end{array}$ \\
\hline SRA1B & $\begin{array}{l}\text { - Rapid economic growth. } \\
\text { The maximum global population in the mid-century and declines } \\
\text { afterwards. } \\
\text { - The rapid development of new and more efficient technologies, with } \\
\text { balance across energy sources. }\end{array}$ \\
\hline SRB1 & $\begin{array}{l}\text { - The same global population as A1 storyline. } \\
\text { - Rapid changes in economic structures towards service and information } \\
\text { economy. } \\
\text { - Reductions in material intensity. } \\
\text { - Introduction of clean and resource-efficient technologies. }\end{array}$ \\
\hline
\end{tabular}




\section{Appendix B: $\mathrm{CO}_{2}$ emission scenarios}

Appendix B.1: Descriptions of different $\mathrm{CO}_{2}$ emission scenarios based on HM Government (2009)

\begin{tabular}{|c|c|}
\hline Scenario & Description \\
\hline $70 \%$ Base & $\begin{array}{l}\mathrm{CO}_{2} \text { reduction targets commissioned by the Committee of Climate } \\
\text { Change }(\mathrm{CCC}) \text { : } \\
29 \% \text { reduction by } 2020 \text { relative to the } 1990 \text { level, } \\
70 \% \text { reduction by } 2050 \text { relative to the } 1990 \text { level. }\end{array}$ \\
\hline $70 \%$ RES & $\begin{array}{l}\mathrm{CO}_{2} \text { reduction targets commissioned by the Department of Energy } \\
\text { and Climate Change (DECC): } \\
29 \% \text { reduction by } 2020 \text { relative to the } 1990 \text { level, } \\
70 \% \text { reduction by } 2050 \text { relative to the } 1990 \text { level. }\end{array}$ \\
\hline $80 \%$ Base & $\begin{array}{l}\mathrm{CO}_{2} \text { reduction targets commissioned by } \mathrm{CCC} \text { : } \\
33 \% \text { reduction by } 2020 \text { relative to the } 1990 \text { level, } \\
80 \% \text { reduction by } 2050 \text { relative to the } 1990 \text { level. }\end{array}$ \\
\hline $\begin{array}{l}80 \% \text { high bio- } \\
\text { energy }\end{array}$ & $\begin{array}{l}\mathrm{CO}_{2} \text { reduction targets commissioned by Department of the } \\
\text { Environment, Fisheries and Rural Affairs (Defra): } \\
31 \% \text { reduction by } 2020 \text { relative to the } 1990 \text { level, } \\
80 \% \text { reduction by } 2050 \text { relative to the } 1990 \text { level. }\end{array}$ \\
\hline $\begin{array}{l}80 \% \text { Resilience } \\
\text { (low-electricity) }\end{array}$ & $\begin{array}{l}\mathrm{CO}_{2} \text { reduction targets commissioned by UK Energy Research } \\
\text { Centre (UKREC): } \\
26 \% \text { reduction by } 2020 \text { relative to the } 1990 \text { level, } \\
80 \% \text { reduction by } 2050 \text { relative to the } 1990 \text { level. }\end{array}$ \\
\hline $80 \%$ RES & $\begin{array}{l}\mathrm{CO}_{2} \text { reduction targets commissioned by DECC: } \\
29 \% \text { reduction by } 2020 \text { relative to the } 1990 \text { level, } \\
80 \% \text { reduction by } 2050 \text { relative to the } 1990 \text { level. }\end{array}$ \\
\hline $90 \%$ Base & $\begin{array}{l}\mathrm{CO}_{2} \text { reduction targets commissioned by CCC: } \\
38 \% \text { reduction by } 2020 \text { relative to the } 1990 \text { level, } \\
90 \% \text { reduction by } 2050 \text { relative to the } 1990 \text { level. }\end{array}$ \\
\hline $90 \%$ RES & $\begin{array}{l}\mathrm{CO}_{2} \text { reduction targets commissioned by DECC: } \\
29 \% \text { reduction by } 2020 \text { relative to the } 1990 \text { level, } \\
90 \% \text { reduction by } 2050 \text { relative to the } 1990 \text { level. }\end{array}$ \\
\hline
\end{tabular}

Appendix B.2: Rate of average carbon emission under different scenarios estimated by HM Government (2009)

\begin{tabular}{|c|c|c|c|c|c|c|c|c|}
\hline \multirow[b]{2}{*}{ Year } & \multicolumn{8}{|c|}{ Average emission/gCO2 per $\mathrm{kWh}$} \\
\hline & $\begin{array}{l}70 \% \\
\text { base }\end{array}$ & $\begin{array}{l}\text { 70\% } \\
\text { RES }\end{array}$ & $\begin{array}{l}80 \% \\
\text { base }\end{array}$ & $\begin{array}{l}80 \% \text { high- } \\
\text { bio energy }\end{array}$ & $\begin{array}{l}\text { 80\% } \\
\text { RES }\end{array}$ & $\begin{array}{c}80 \% \\
\text { resilient }\end{array}$ & $\begin{array}{l}90 \% \\
\text { base }\end{array}$ & $\begin{array}{l}90 \% \\
\text { RES }\end{array}$ \\
\hline 2017 & 480 & 400 & 450 & 420 & 390 & 490 & 430 & 400 \\
\hline 2030 & 180 & 160 & 70 & 100 & 80 & 220 & 25 & 25 \\
\hline 2050 & 50 & 45 & 25 & 30 & 20 & 16 & 17 & 18 \\
\hline 2080 & 50 & 45 & 25 & 30 & 20 & 16 & 17 & 18 \\
\hline
\end{tabular}


Appendix C: Breakdown of results

Appendix C.1: Breakdown of actual measured results for 2017

\begin{tabular}{|c|c|c|c|c|c|c|c|c|c|c|}
\hline & & & & & 2017 & & & & & \\
\hline & & & & & & $\mathrm{CO}_{2}$ emissi & $\mathrm{ns} / \mathrm{kgCO}$ & & & \\
\hline Month & HDD & $\begin{array}{c}\text { Energy } \\
\text { consumption } \\
/ \mathbf{k W h}\end{array}$ & $70 \%$ base & $70 \%$ RES & $80 \%$ base & $\begin{array}{c}80 \% \\
\text { high-bio } \\
\text { energy }\end{array}$ & $80 \%$ RES & $\begin{array}{c}\mathbf{8 0 \%} \\
\text { resilient }\end{array}$ & $90 \%$ base & $\begin{array}{l}90 \% \\
\text { RES }\end{array}$ \\
\hline January & 178.41 & $10,449.14$ & $5,015.58$ & $4,179.65$ & $4,702.11$ & $4,388.64$ & $4,075.16$ & $5,120.08$ & $4,493.13$ & $4,179.65$ \\
\hline February & 76.11 & $6,696.65$ & $3,214.39$ & $2,678.66$ & $3,013.49$ & $2,812.59$ & $2,611.69$ & $3,281.36$ & $2,879.56$ & $2,678.66$ \\
\hline March & 42.70 & $6,163.78$ & $2,958.61$ & $2,465.51$ & $2,773.70$ & $2,588.79$ & $2,403.87$ & $3,020.25$ & $2,650.42$ & $2,465.51$ \\
\hline October & 13.34 & $7,285.66$ & $3,497.12$ & $2,914.26$ & $3,278.55$ & $3,059.98$ & $2,841.41$ & $3,569.97$ & $3,132.83$ & $2,914.26$ \\
\hline November & 94.52 & $8,744.91$ & $4,197.56$ & $3,497.96$ & $3,935.21$ & $3,672.86$ & $3,410.51$ & $4,285.01$ & $3,760.31$ & $3,497.96$ \\
\hline December & 84.03 & $4,688.72$ & $2,250.59$ & $1,875.49$ & $2,109.93$ & $1,969.26$ & $1,828.60$ & $2,297.47$ & $2,016.15$ & $1,875.49$ \\
\hline Total & 489.11 & $44,028.85$ & $21,133.85$ & $17,611.54$ & $19,812.98$ & $18,492.12$ & $17,171.25$ & $21,574.14$ & $18,932.41$ & $17,611.54$ \\
\hline
\end{tabular}

Appendix C.2: Breakdown of results for the standard reference period between 1961 and 1990 Standard reference period between 1961-1990

\begin{tabular}{|l|r|r|r|}
\hline \multicolumn{1}{|c|}{ Month } & \multicolumn{1}{c|}{ HDD } & $\begin{array}{c}\text { Energy consumption } \\
\text { /kWh }\end{array}$ & $\begin{array}{c}\text { CO2 emissions } \\
\text { /kgCO2 }\end{array}$ \\
\hline January & 148.25 & $8,986.91$ & $6,830.05$ \\
\hline February & 147.61 & $8,976.84$ & $6,822.40$ \\
\hline March & 114.11 & $9,122.99$ & $6,933.47$ \\
\hline October & 32.50 & $7,844.35$ & $5,961.70$ \\
\hline November & 105.09 & $8,648.86$ & $6,573.13$ \\
\hline December & 37.98 & $3,595.73$ & $2,732.75$ \\
\hline Total & $\mathbf{5 8 5 . 5 4}$ & $\mathbf{4 7 , 1 7 5 . 6 7}$ & $\mathbf{3 5 , 8 5 3 . 5 1}$ \\
\hline
\end{tabular}


Appendix C.3: Breakdown of results for 2030 under medium emission scenario

\begin{tabular}{|c|c|c|c|c|c|c|c|c|c|c|c|}
\hline \multicolumn{12}{|c|}{2030 (medium emission) } \\
\hline \multirow[b]{2}{*}{$\begin{array}{c}\text { Probability } \\
/ \%\end{array}$} & \multirow[b]{2}{*}{ Month } & \multirow[b]{2}{*}{ HDD } & \multirow[b]{2}{*}{$\begin{array}{c}\text { Energy } \\
\text { consumption } \\
/ \mathbf{k W h}\end{array}$} & \multicolumn{8}{|c|}{$\mathrm{CO}_{2}$ emissions/kgCO 2} \\
\hline & & & & $\begin{array}{l}70 \% \\
\text { base }\end{array}$ & $\begin{array}{l}\text { 70\% } \\
\text { RES }\end{array}$ & $\begin{array}{l}80 \% \\
\text { base }\end{array}$ & $\begin{array}{c}\mathbf{8 0} \% \\
\text { high-bio } \\
\text { energy }\end{array}$ & $\begin{array}{l}\mathbf{8 0} \% \\
\text { RES }\end{array}$ & $\begin{array}{c}80 \% \\
\text { resilient }\end{array}$ & $\begin{array}{l}90 \% \\
\text { base }\end{array}$ & $\begin{array}{l}90 \% \\
\text { RES }\end{array}$ \\
\hline \multirow[t]{7}{*}{10} & January & 155.41 & $9,099.13$ & $1,637.84$ & $1,455.86$ & 636.94 & 909.91 & 727.93 & $2,001.81$ & 227.48 & 227.48 \\
\hline & February & 130.23 & $8,706.75$ & $1,567.21$ & $1,393.08$ & 609.47 & 870.67 & 696.54 & $1,915.48$ & 217.67 & 217.67 \\
\hline & March & 81.11 & $7,606.24$ & $1,369.12$ & $1,217.00$ & 532.44 & 760.62 & 608.50 & $1,673.37$ & 190.16 & 190.16 \\
\hline & October & 21.02 & $6,330.72$ & $1,139.53$ & $1,012.92$ & 443.15 & 633.07 & 506.46 & $1,392.76$ & 158.27 & 158.27 \\
\hline & November & 80.85 & $8,268.65$ & $1,488.36$ & $1,322.98$ & 578.81 & 826.86 & 661.49 & $1,819.10$ & 206.72 & 206.72 \\
\hline & December & 67.55 & $3,724.09$ & 670.34 & 595.86 & 260.69 & 372.41 & 297.93 & 819.30 & 93.10 & 93.10 \\
\hline & Total & 536.17 & $43,735.57$ & $7,872.40$ & $6,997.69$ & $3,061.49$ & $4,373.56$ & $3,498.85$ & $9,621.83$ & $1,093.39$ & $1,093.39$ \\
\hline \multirow[t]{7}{*}{33} & January & 139.77 & $9,188.63$ & $1,653.95$ & $1,470.18$ & 643.20 & 918.86 & 735.09 & $2,021.50$ & 229.72 & 229.72 \\
\hline & February & 112.80 & $8,435.29$ & $1,518.35$ & $1,349.65$ & 590.47 & 843.53 & 674.82 & $1,855.76$ & 210.88 & 210.88 \\
\hline & March & 71.64 & $8,124.96$ & $1,462.49$ & $1,299.99$ & 568.75 & 812.50 & 650.00 & $1,787.49$ & 203.12 & 203.12 \\
\hline & October & 12.89 & $5,536.19$ & 996.51 & 885.79 & 387.53 & 553.62 & 442.90 & $1,217.96$ & 138.40 & 138.40 \\
\hline & November & 60.66 & $7,285.92$ & $1,311.47$ & $1,165.75$ & 510.01 & 728.59 & 582.87 & $1,602.90$ & 182.15 & 182.15 \\
\hline & December & 51.67 & $4,143.71$ & 745.87 & 662.99 & 290.06 & 414.37 & 331.50 & 911.62 & 103.59 & 103.59 \\
\hline & Total & 449.43 & $42,714.70$ & $7,688.65$ & $6,834.35$ & $2,990.03$ & $4,271.47$ & $3,417.18$ & $9,397.23$ & $1,067.87$ & $1,067.87$ \\
\hline \multirow[t]{7}{*}{50} & January & 128.94 & $8,687.53$ & $1,563.75$ & $1,390.00$ & 608.13 & 868.75 & 695.00 & $1,911.26$ & 217.19 & 217.19 \\
\hline & February & 108.62 & $8,369.58$ & $1,506.52$ & $1,339.13$ & 585.87 & 836.96 & 669.57 & $1,841.31$ & 209.24 & 209.24 \\
\hline & March & 57.88 & $7,575.81$ & $1,363.65$ & $1,212.13$ & 530.31 & 757.58 & 606.06 & $1,666.68$ & 189.40 & 189.40 \\
\hline & October & 14.53 & $5,895.22$ & $1,061.14$ & 943.23 & 412.67 & 589.52 & 471.62 & $1,296.95$ & 147.38 & 147.38 \\
\hline & November & 53.85 & $7,846.04$ & $1,412.29$ & $1,255.37$ & 549.22 & 784.60 & 627.68 & $1,726.13$ & 196.15 & 196.15 \\
\hline & December & 68.59 & $4,073.15$ & 733.17 & 651.70 & 285.12 & 407.32 & 325.85 & 896.09 & 101.83 & 101.83 \\
\hline & Total & 432.41 & $42,447.33$ & $7,640.52$ & $6,791.57$ & $2,971.31$ & $4,244.73$ & $3,395.79$ & $9,338.41$ & $1,061.18$ & $1,061.18$ \\
\hline
\end{tabular}




\begin{tabular}{|c|c|c|c|c|c|c|c|c|c|c|c|}
\hline \multicolumn{12}{|c|}{2030 (medium emission) } \\
\hline \multirow[b]{2}{*}{$\begin{array}{c}\text { Probability } \\
/ \%\end{array}$} & \multirow[b]{2}{*}{ Month } & \multirow[b]{2}{*}{ HDD } & \multirow[b]{2}{*}{$\begin{array}{c}\text { Energy } \\
\text { consumption } \\
/ \mathbf{k W h}\end{array}$} & \multicolumn{8}{|c|}{$\mathrm{CO}_{2}$ emissions/kgCO} \\
\hline & & & & $\begin{array}{l}70 \% \\
\text { base }\end{array}$ & $\begin{array}{l}70 \% \\
\text { RES }\end{array}$ & $\begin{array}{l}80 \% \\
\text { base }\end{array}$ & $\begin{array}{c}80 \% \\
\text { high-bio } \\
\text { energy }\end{array}$ & $\begin{array}{l}\text { 80\% } \\
\text { RES }\end{array}$ & $\begin{array}{c}80 \% \\
\text { resilient }\end{array}$ & $\begin{array}{l}90 \% \\
\text { base }\end{array}$ & $\begin{array}{l}90 \% \\
\text { RES }\end{array}$ \\
\hline \multirow[t]{7}{*}{66} & January & 121.77 & $8,908.84$ & $1,603.59$ & $1,425.41$ & 623.62 & 890.88 & 712.71 & $1,959.94$ & 222.72 & 222.72 \\
\hline & February & 96.81 & $8,185.47$ & $1,473.38$ & $1,309.68$ & 572.98 & 818.55 & 654.84 & $1,800.80$ & 204.64 & 204.64 \\
\hline & March & 63.20 & $7,992.64$ & $1,438.68$ & $1,278.82$ & 559.48 & 799.26 & 639.41 & $1,758.38$ & 199.82 & 199.82 \\
\hline & October & 10.27 & $4,828.29$ & 869.09 & 772.53 & 337.98 & 482.83 & 386.26 & $1,062.22$ & 120.71 & 120.71 \\
\hline & November & 41.54 & $7,652.76$ & $1,377.50$ & $1,224.44$ & 535.69 & 765.28 & 612.22 & $1,683.61$ & 191.32 & 191.32 \\
\hline & December & 24.21 & $3,714.02$ & 668.52 & 594.24 & 259.98 & 371.40 & 297.12 & 817.08 & 92.85 & 92.85 \\
\hline & Total & 357.80 & $41,282.02$ & $7,430.76$ & $6,605.12$ & $2,889.74$ & $4,128.20$ & $3,302.56$ & $9,082.05$ & $1,032.05$ & $1,032.05$ \\
\hline \multirow[t]{7}{*}{90} & January & 86.98 & $8,364.03$ & $1,505.53$ & $1,338.25$ & 585.48 & 836.40 & 669.12 & $1,840.09$ & 209.10 & 209.10 \\
\hline & February & 75.93 & $7,858.42$ & $1,414.52$ & $1,257.35$ & 550.09 & 785.84 & 628.67 & $1,728.85$ & 196.46 & 196.46 \\
\hline & March & 56.37 & $7,552.41$ & $1,359.43$ & $1,208.39$ & 528.67 & 755.24 & 604.19 & $1,661.53$ & 188.81 & 188.81 \\
\hline & October & 7.64 & $4,786.87$ & 861.64 & 765.90 & 335.08 & 478.69 & 382.95 & $1,053.11$ & 119.67 & 119.67 \\
\hline & November & 29.37 & $6,795.14$ & $1,223.13$ & $1,087.22$ & 475.66 & 679.51 & 543.61 & $1,494.93$ & 169.88 & 169.88 \\
\hline & December & 20.24 & $3,318.28$ & 597.29 & 530.92 & 232.28 & 331.83 & 265.46 & 730.02 & 82.96 & 82.96 \\
\hline & Total & 276.53 & $38,675.15$ & $6,961.53$ & $6,188.02$ & $2,707.26$ & $3,867.51$ & $3,094.01$ & $8,508.53$ & 966.88 & 966.88 \\
\hline
\end{tabular}


Appendix C.4: Breakdown of results for 2030 under high emission scenario

\begin{tabular}{|c|c|c|c|c|c|c|c|c|c|c|c|}
\hline \multicolumn{12}{|c|}{2030 (high emission) } \\
\hline \multirow[b]{2}{*}{$\begin{array}{c}\text { Probability } \\
/ \%\end{array}$} & \multirow[b]{2}{*}{ Month } & \multirow[b]{2}{*}{ HDD } & \multirow[b]{2}{*}{$\begin{array}{c}\text { Energy } \\
\text { consumption } \\
/ \mathbf{k W h}\end{array}$} & \multicolumn{8}{|c|}{$\mathrm{CO}_{2}$ emissions/kgCO} \\
\hline & & & & $\begin{array}{l}70 \% \\
\text { base }\end{array}$ & $\begin{array}{l}\text { 70\% } \\
\text { RES }\end{array}$ & $\begin{array}{l}80 \% \\
\text { base }\end{array}$ & $\begin{array}{c}80 \% \\
\text { high- } \\
\text { bio } \\
\text { energy }\end{array}$ & $\begin{array}{l}\mathbf{8 0} \% \\
\text { RES }\end{array}$ & $\begin{array}{c}\mathbf{8 0 \%} \\
\text { resilient }\end{array}$ & $\begin{array}{l}90 \% \\
\text { base }\end{array}$ & $\begin{array}{l}90 \% \\
\text { RES }\end{array}$ \\
\hline \multirow[t]{7}{*}{10} & January & 163.44 & $9,225.20$ & $1,660.54$ & $1,476.03$ & 645.76 & 922.52 & 738.02 & $2,029.54$ & 230.63 & 230.63 \\
\hline & February & 119.22 & $8,202.31$ & $1,476.42$ & $1,312.37$ & 574.16 & 820.23 & 656.18 & $1,804.51$ & 205.06 & 205.06 \\
\hline & March & 82.43 & $8,294.03$ & $1,492.93$ & $1,327.04$ & 580.58 & 829.40 & 663.52 & $1,824.69$ & 207.35 & 207.35 \\
\hline & October & 22.49 & $6,686.89$ & $1,203.64$ & $1,069.90$ & 468.08 & 668.69 & 534.95 & $1,471.12$ & 167.17 & 167.17 \\
\hline & November & 66.62 & $7,379.13$ & $1,328.24$ & $1,180.66$ & 516.54 & 737.91 & 590.33 & $1,623.41$ & 184.48 & 184.48 \\
\hline & December & 52.82 & $3,828.24$ & 689.08 & 612.52 & 267.98 & 382.82 & 306.26 & 842.21 & 95.71 & 95.71 \\
\hline & Total & 507.02 & $43,615.80$ & $7,850.84$ & $6,978.53$ & $3,053.11$ & $4,361.58$ & $3,489.26$ & $9,595.48$ & $1,090.40$ & $1,090.40$ \\
\hline \multirow[t]{7}{*}{33} & January & 131.53 & $8,726.73$ & $1,570.81$ & $1,396.28$ & 610.87 & 872.67 & 698.14 & $1,919.88$ & 218.17 & 218.17 \\
\hline & February & 98.57 & $8,213.23$ & $1,478.38$ & $1,314.12$ & 574.93 & 821.32 & 657.06 & $1,806.91$ & 205.33 & 205.33 \\
\hline & March & 75.45 & $7,851.21$ & $1,413.22$ & $1,256.19$ & 549.58 & 785.12 & 628.10 & $1,727.27$ & 196.28 & 196.28 \\
\hline & October & 13.41 & $5,877.70$ & $1,057.99$ & 940.43 & 411.44 & 587.77 & 470.22 & $1,293.10$ & 146.94 & 146.94 \\
\hline & November & 60.37 & $7,948.40$ & $1,430.71$ & $1,271.74$ & 556.39 & 794.84 & 635.87 & $1,748.65$ & 198.71 & 198.71 \\
\hline & December & 52.31 & $4,153.61$ & 747.65 & 664.58 & 290.75 & 415.36 & 332.29 & 913.79 & 103.84 & 103.84 \\
\hline & Total & 431.64 & $42,770.88$ & $7,698.76$ & $6,843.34$ & $2,993.96$ & $4,277.09$ & $3,421.67$ & $9,409.59$ & $1,069.27$ & $1,069.27$ \\
\hline \multirow[t]{7}{*}{50} & January & 124.44 & $8,949.77$ & $1,610.96$ & $1,431.96$ & 626.48 & 894.98 & 715.98 & $1,968.95$ & 223.74 & 223.74 \\
\hline & February & 98.12 & $8,205.28$ & $1,476.95$ & $1,312.85$ & 574.37 & 820.53 & 656.42 & $1,805.16$ & 205.13 & 205.13 \\
\hline & March & 75.59 & $8,186.97$ & $1,473.65$ & $1,309.92$ & 573.09 & 818.70 & 654.96 & $1,801.13$ & 204.67 & 204.67 \\
\hline & October & 11.43 & $5,513.20$ & 992.38 & 882.11 & 385.92 & 551.32 & 441.06 & $1,212.90$ & 137.83 & 137.83 \\
\hline & November & 57.94 & $7,243.02$ & $1,303.74$ & $1,158.88$ & 507.01 & 724.30 & 579.44 & $1,593.46$ & 181.08 & 181.08 \\
\hline & December & 51.85 & $4,146.68$ & 746.40 & 663.47 & 290.27 & 414.67 & 331.73 & 912.27 & 103.67 & 103.67 \\
\hline & Total & 419.37 & $42,244.92$ & $7,604.09$ & $6,759.19$ & $2,957.14$ & $4,224.49$ & $3,379.59$ & $9,293.88$ & $1,056.12$ & $1,056.12$ \\
\hline
\end{tabular}




\begin{tabular}{|c|c|c|c|c|c|c|c|c|c|c|c|}
\hline \multicolumn{12}{|c|}{2030 (high emission) } \\
\hline \multirow[b]{2}{*}{$\begin{array}{c}\text { Probability } \\
/ \%\end{array}$} & \multirow[b]{2}{*}{ Month } & \multirow[b]{2}{*}{ HDD } & \multirow[b]{2}{*}{$\begin{array}{c}\text { Energy } \\
\text { consumption } \\
/ \mathbf{k W h}\end{array}$} & \multicolumn{8}{|c|}{$\mathrm{CO}_{2}$ emissions $/ \mathrm{kgCO}_{2}$} \\
\hline & & & & $\begin{array}{l}70 \% \\
\text { base }\end{array}$ & $\begin{array}{l}70 \% \\
\text { RES }\end{array}$ & $\begin{array}{l}80 \% \\
\text { base }\end{array}$ & $\begin{array}{c}\mathbf{8 0} \% \\
\text { high- } \\
\text { bio } \\
\text { energy } \\
\end{array}$ & $\begin{array}{l}\mathbf{8 0} \% \\
\text { RES }\end{array}$ & $\begin{array}{c}80 \% \\
\text { resilient }\end{array}$ & $\begin{array}{l}90 \% \\
\text { base }\end{array}$ & $\begin{array}{l}90 \% \\
\text { RES }\end{array}$ \\
\hline \multirow[t]{7}{*}{66} & January & 127.52 & $8,331.44$ & $1,499.66$ & $1,333.03$ & 583.20 & 833.14 & 666.52 & $1,832.92$ & 208.29 & 208.29 \\
\hline & February & 93.66 & $8,136.75$ & $1,464.62$ & $1,301.88$ & 569.57 & 813.68 & 650.94 & $1,790.09$ & 203.42 & 203.42 \\
\hline & March & 67.23 & $8,056.40$ & $1,450.15$ & $1,289.02$ & 563.95 & 805.64 & 644.51 & $1,772.41$ & 201.41 & 201.41 \\
\hline & October & 11.28 & $6,177.48$ & $1,111.95$ & 988.40 & 432.42 & 617.75 & 494.20 & $1,359.05$ & 154.44 & 154.44 \\
\hline & November & 55.99 & $6,879.40$ & $1,238.29$ & $1,100.70$ & 481.56 & 687.94 & 550.35 & $1,513.47$ & 171.98 & 171.98 \\
\hline & December & 72.35 & $4,464.78$ & 803.66 & 714.36 & 312.53 & 446.48 & 357.18 & 982.25 & 111.62 & 111.62 \\
\hline & Total & 428.03 & $42,046.26$ & $7,568.33$ & $6,727.40$ & $2,943.24$ & $4,204.63$ & $3,363.70$ & $9,250.18$ & $1,051.16$ & $1,051.16$ \\
\hline \multirow[t]{7}{*}{90} & January & 108.36 & $8,031.33$ & $1,445.64$ & $1,285.01$ & 562.19 & 803.13 & 642.51 & $1,766.89$ & 200.78 & 200.78 \\
\hline & February & 79.69 & $7,584.24$ & $1,365.16$ & $1,213.48$ & 530.90 & 758.42 & 606.74 & $1,668.53$ & 189.61 & 189.61 \\
\hline & March & 65.89 & $8,035.16$ & $1,446.33$ & $1,285.62$ & 562.46 & 803.52 & 642.81 & $1,767.73$ & 200.88 & 200.88 \\
\hline & October & 9.40 & $4,814.52$ & 866.61 & 770.32 & 337.02 & 481.45 & 385.16 & $1,059.19$ & 120.36 & 120.36 \\
\hline & November & 27.20 & $7,094.66$ & $1,277.04$ & $1,135.15$ & 496.63 & 709.47 & 567.57 & $1,560.82$ & 177.37 & 177.37 \\
\hline & December & 47.86 & $4,084.60$ & 735.23 & 653.54 & 285.92 & 408.46 & 326.77 & 898.61 & 102.12 & 102.12 \\
\hline & Total & 338.40 & $39,644.51$ & $7,136.01$ & $6,343.12$ & $2,775.12$ & $3,964.45$ & $3,171.56$ & $8,721.79$ & 991.11 & 991.11 \\
\hline
\end{tabular}


Appendix D.5: Breakdown of results for 2050 under medium emission scenario

\begin{tabular}{|c|c|c|c|c|c|c|c|c|c|c|c|}
\hline \multicolumn{12}{|c|}{2050 (medium emission) } \\
\hline \multirow[b]{2}{*}{$\begin{array}{c}\text { Probability } \\
/ \%\end{array}$} & \multirow[b]{2}{*}{ Month } & \multirow[b]{2}{*}{ HDD } & \multirow[b]{2}{*}{$\begin{array}{c}\text { Energy } \\
\text { consumption } \\
/ \mathbf{k W h}\end{array}$} & \multicolumn{8}{|c|}{$\mathrm{CO}_{2}$ emissions//kgCO 2} \\
\hline & & & & $\begin{array}{l}70 \% \\
\text { base }\end{array}$ & $\begin{array}{l}\text { 70\% } \\
\text { RES }\end{array}$ & $\begin{array}{l}80 \% \\
\text { base }\end{array}$ & $\begin{array}{c}80 \% \\
\text { high-bio } \\
\text { energy }\end{array}$ & $\begin{array}{l}80 \% \\
\text { RES }\end{array}$ & $\begin{array}{c}80 \% \\
\text { resilient }\end{array}$ & $\begin{array}{l}90 \% \\
\text { base }\end{array}$ & $\begin{array}{l}\text { 90\% } \\
\text { RES }\end{array}$ \\
\hline \multirow[t]{7}{*}{10} & January & 146.82 & $8,964.29$ & 448.21 & 403.39 & 224.11 & 268.93 & 179.29 & 143.43 & 152.39 & 161.36 \\
\hline & February & 129.81 & $8,698.88$ & 434.94 & 391.45 & 217.47 & 260.97 & 173.98 & 139.18 & 147.88 & 156.58 \\
\hline & March & 88.94 & $9,062.51$ & 453.13 & 407.81 & 226.56 & 271.88 & 181.25 & 145.00 & 154.06 & 163.13 \\
\hline & October & 10.64 & $5,167.42$ & 258.37 & 232.53 & 129.19 & 155.02 & 103.35 & 82.68 & 87.85 & 93.01 \\
\hline & November & 76.58 & $8,536.02$ & 426.80 & 384.12 & 213.40 & 256.08 & 170.72 & 136.58 & 145.11 & 153.65 \\
\hline & December & 35.28 & $2,886.90$ & 144.35 & 129.91 & 72.17 & 86.61 & 57.74 & 46.19 & 49.08 & 51.96 \\
\hline & Total & 488.07 & $43,316.02$ & $2,165.80$ & $1,949.22$ & $1,082.90$ & $1,299.48$ & 866.32 & 693.06 & 736.37 & 779.69 \\
\hline \multirow[t]{7}{*}{33} & January & 123.34 & $8,600.45$ & 430.02 & 387.02 & 215.01 & 258.01 & 172.01 & 137.61 & 146.21 & 154.81 \\
\hline & February & 113.38 & $8,443.40$ & 422.17 & 379.95 & 211.08 & 253.30 & 168.87 & 135.09 & 143.54 & 151.98 \\
\hline & March & 73.41 & $8,819.79$ & 440.99 & 396.89 & 220.49 & 264.59 & 176.40 & 141.12 & 149.94 & 158.76 \\
\hline & October & 11.07 & $5,507.50$ & 275.37 & 247.84 & 137.69 & 165.22 & 110.15 & 88.12 & 93.63 & 99.13 \\
\hline & November & 46.63 & $7,733.34$ & 386.67 & 348.00 & 193.33 & 232.00 & 154.67 & 123.73 & 131.47 & 139.20 \\
\hline & December & 28.07 & $2,773.79$ & 138.69 & 124.82 & 69.34 & 83.21 & 55.48 & 44.38 & 47.15 & 49.93 \\
\hline & Total & 395.90 & $41,878.27$ & $2,093.91$ & $1,884.52$ & $1,046.96$ & $1,256.35$ & 837.57 & 670.05 & 711.93 & 753.81 \\
\hline \multirow[t]{7}{*}{50} & January & 120.01 & $8,545.58$ & 427.28 & 384.55 & 213.64 & 256.37 & 170.91 & 136.73 & 145.27 & 153.82 \\
\hline & February & 100.73 & $8,246.20$ & 412.31 & 371.08 & 206.15 & 247.39 & 164.92 & 131.94 & 140.19 & 148.43 \\
\hline & March & 71.57 & $8,790.57$ & 439.53 & 395.58 & 219.76 & 263.72 & 175.81 & 140.65 & 149.44 & 158.23 \\
\hline & October & 7.07 & $4,444.53$ & 222.23 & 200.00 & 111.11 & 133.34 & 88.89 & 71.11 & 75.56 & 80.00 \\
\hline & November & 52.75 & $7,162.10$ & 358.11 & 322.29 & 179.05 & 214.86 & 143.24 & 114.59 & 121.76 & 128.92 \\
\hline & December & 27.75 & $2,768.95$ & 138.45 & 124.60 & 69.22 & 83.07 & 55.38 & 44.30 & 47.07 & 49.84 \\
\hline & Total & 379.88 & $39,957.93$ & $1,997.90$ & $1,798.11$ & 998.95 & $1,198.74$ & 799.16 & 639.33 & 679.28 & 719.24 \\
\hline
\end{tabular}




\begin{tabular}{|c|c|c|c|c|c|c|c|c|c|c|c|}
\hline \multicolumn{12}{|c|}{2050 (medium emission) } \\
\hline \multirow[b]{2}{*}{$\begin{array}{c}\text { Probability } \\
/ \%\end{array}$} & \multirow[b]{2}{*}{ Month } & \multirow[b]{2}{*}{ HDD } & \multirow[b]{2}{*}{$\begin{array}{c}\text { Energy } \\
\text { consumption } \\
/ \mathbf{k W h}\end{array}$} & \multicolumn{8}{|c|}{$\mathrm{CO}_{2}$ emissions $/ \mathrm{kgCO}_{2}$} \\
\hline & & & & $\begin{array}{l}70 \% \\
\text { base }\end{array}$ & $\begin{array}{l}70 \% \\
\text { RES }\end{array}$ & $\begin{array}{l}80 \% \\
\text { base }\end{array}$ & $\begin{array}{c}80 \% \\
\text { high-bio } \\
\text { energy }\end{array}$ & $\begin{array}{l}\text { 80\% } \\
\text { RES }\end{array}$ & $\begin{array}{l}\mathbf{8 0 \%} \\
\text { resilient }\end{array}$ & $\begin{array}{l}90 \% \\
\text { base }\end{array}$ & $\begin{array}{l}90 \% \\
\text { RES }\end{array}$ \\
\hline \multirow[t]{7}{*}{66} & January & 102.15 & $7,934.95$ & 396.75 & 357.07 & 198.37 & 238.05 & 158.70 & 126.96 & 134.89 & 142.83 \\
\hline & February & 106.32 & $8,333.86$ & 416.69 & 375.02 & 208.35 & 250.02 & 166.68 & 133.34 & 141.68 & 150.01 \\
\hline & March & 70.24 & $8,436.43$ & 421.82 & 379.64 & 210.91 & 253.09 & 168.73 & 134.98 & 143.42 & 151.86 \\
\hline & October & 4.73 & $4,074.40$ & 203.72 & 183.35 & 101.86 & 122.23 & 81.49 & 65.19 & 69.26 & 73.34 \\
\hline & November & 34.73 & $7,546.25$ & 377.31 & 339.58 & 188.66 & 226.39 & 150.92 & 120.74 & 128.29 & 135.83 \\
\hline & December & 31.50 & $2,827.95$ & 141.40 & 127.26 & 70.70 & 84.84 & 56.56 & 45.25 & 48.08 & 50.90 \\
\hline & Total & 349.67 & $39,153.84$ & $1,957.69$ & $1,761.92$ & 978.85 & $1,174.62$ & 783.08 & 626.46 & 665.62 & 704.77 \\
\hline \multirow[t]{7}{*}{90} & January & 76.81 & $7,538.90$ & 376.94 & 339.25 & 188.47 & 226.17 & 150.78 & 120.62 & 128.16 & 135.70 \\
\hline & February & 61.70 & $7,635.87$ & 381.79 & 343.61 & 190.90 & 229.08 & 152.72 & 122.17 & 129.81 & 137.45 \\
\hline & March & 42.90 & $8,007.72$ & 400.39 & 360.35 & 200.19 & 240.23 & 160.15 & 128.12 & 136.13 & 144.14 \\
\hline & October & 4.75 & $4,408.02$ & 220.40 & 198.36 & 110.20 & 132.24 & 88.16 & 70.53 & 74.94 & 79.34 \\
\hline & November & 30.62 & $6,148.22$ & 307.41 & 276.67 & 153.71 & 184.45 & 122.96 & 98.37 & 104.52 & 110.67 \\
\hline & December & 16.52 & $2,259.48$ & 112.97 & 101.68 & 56.49 & 67.78 & 45.19 & 36.15 & 38.41 & 40.67 \\
\hline & Total & 233.30 & $35,998.21$ & $1,799.91$ & $1,619.92$ & 899.96 & $1,079.95$ & 719.96 & $\mathbf{5 7 5 . 9 7}$ & 611.97 & 647.97 \\
\hline
\end{tabular}


Appendix D.6: Breakdown of results for 2050 under high emission scenario 2050 (high emission)

\begin{tabular}{|c|c|c|c|c|c|c|c|c|c|c|c|}
\hline & & & & \multicolumn{8}{|c|}{$\mathrm{CO}_{2}$ emissions/kgCO} \\
\hline $\begin{array}{c}\text { Probability } \\
/ \%\end{array}$ & Month & HDD & $\begin{array}{c}\text { Energy } \\
\text { consumption } \\
/ \mathbf{k W h}\end{array}$ & $\begin{array}{l}70 \% \\
\text { base }\end{array}$ & $\begin{array}{l}\text { 70\% } \\
\text { RES }\end{array}$ & $\begin{array}{l}80 \% \\
\text { base }\end{array}$ & $\begin{array}{c}80 \% \\
\text { high-bio } \\
\text { energy }\end{array}$ & $\begin{array}{l}\mathbf{8 0 \%} \\
\text { RES }\end{array}$ & $\begin{array}{c}\mathbf{8 0 \%} \\
\text { resilient }\end{array}$ & $\begin{array}{l}90 \% \\
\text { base }\end{array}$ & $\begin{array}{l}90 \% \\
\text { RES }\end{array}$ \\
\hline \multirow[t]{7}{*}{10} & January & 143.65 & $8,916.56$ & 445.83 & 401.25 & 222.91 & 267.50 & 178.33 & 142.67 & 151.58 & 160.50 \\
\hline & February & 100.88 & $8,248.86$ & 412.44 & 371.20 & 206.22 & 247.47 & 164.98 & 131.98 & 140.23 & 148.48 \\
\hline & March & 97.30 & $8,860.07$ & 443.00 & 398.70 & 221.50 & 265.80 & 177.20 & 141.76 & 150.62 & 159.48 \\
\hline & October & 10.83 & $5,837.07$ & 291.85 & 262.67 & 145.93 & 175.11 & 116.74 & 93.39 & 99.23 & 105.07 \\
\hline & November & 67.25 & $7,389.02$ & 369.45 & 332.51 & 184.73 & 221.67 & 147.78 & 118.22 & 125.61 & 133.00 \\
\hline & December & 64.67 & $3,343.30$ & 167.16 & 150.45 & 83.58 & 100.30 & 66.87 & 53.49 & 56.84 & 60.18 \\
\hline & Total & 484.58 & $42,594.88$ & $2,129.74$ & $1,916.77$ & $1,064.87$ & $1,277.85$ & 851.90 & 681.52 & 724.11 & 766.71 \\
\hline \multirow[t]{7}{*}{33} & January & 110.81 & $8,403.67$ & 420.18 & 378.17 & 210.09 & 252.11 & 168.07 & 134.46 & 142.86 & 151.27 \\
\hline & February & 111.68 & $8,418.12$ & 420.91 & 378.82 & 210.45 & 252.54 & 168.36 & 134.69 & 143.11 & 151.53 \\
\hline & March & 75.12 & $8,512.61$ & 425.63 & 383.07 & 212.82 & 255.38 & 170.25 & 136.20 & 144.71 & 153.23 \\
\hline & October & 10.87 & $5,837.64$ & 291.88 & 262.69 & 145.94 & 175.13 & 116.75 & 93.40 & 99.24 & 105.08 \\
\hline & November & 56.81 & $7,225.78$ & 361.29 & 325.16 & 180.64 & 216.77 & 144.52 & 115.61 & 122.84 & 130.06 \\
\hline & December & 41.38 & $2,982.55$ & 149.13 & 134.21 & 74.56 & 89.48 & 59.65 & 47.72 & 50.70 & 53.69 \\
\hline & Total & 406.67 & $41,380.36$ & $2,069.02$ & $1,862.12$ & $1,034.51$ & $1,241.41$ & 827.61 & 662.09 & 703.47 & 744.85 \\
\hline \multirow[t]{7}{*}{50} & January & 101.24 & $7,920.99$ & 396.05 & 356.44 & 198.02 & 237.63 & 158.42 & 126.74 & 134.66 & 142.58 \\
\hline & February & 84.61 & $7,994.75$ & 399.74 & 359.76 & 199.87 & 239.84 & 159.89 & 127.92 & 135.91 & 143.91 \\
\hline & March & 48.59 & $8,430.84$ & 421.54 & 379.39 & 210.77 & 252.93 & 168.62 & 134.89 & 143.32 & 151.76 \\
\hline & October & 9.27 & $5,145.02$ & 257.25 & 231.53 & 128.63 & 154.35 & 102.90 & 82.32 & 87.47 & 92.61 \\
\hline & November & 45.58 & $7,049.85$ & 352.49 & 317.24 & 176.25 & 211.50 & 141.00 & 112.80 & 119.85 & 126.90 \\
\hline & December & 49.98 & $3,116.70$ & 155.84 & 140.25 & 77.92 & 93.50 & 62.33 & 49.87 & 52.98 & 56.10 \\
\hline & Total & 339.27 & $39,658.15$ & $1,982.91$ & $1,784.62$ & 991.45 & $1,189.74$ & 793.16 & 634.53 & 674.19 & 713.85 \\
\hline
\end{tabular}




\begin{tabular}{|c|c|c|c|c|c|c|c|c|c|c|c|}
\hline \multicolumn{12}{|c|}{2050 (high emission) } \\
\hline \multirow[b]{2}{*}{$\begin{array}{c}\text { Probability } \\
\qquad / \%\end{array}$} & \multirow[b]{2}{*}{ Month } & \multirow[b]{2}{*}{ HDD } & \multirow[b]{2}{*}{$\begin{array}{c}\text { Energy } \\
\text { consumption } \\
/ \mathbf{k W h}\end{array}$} & \multicolumn{8}{|c|}{$\mathrm{CO}_{2}$ emissions/kgCO} \\
\hline & & & & $\begin{array}{l}70 \% \\
\text { base }\end{array}$ & $\begin{array}{l}70 \% \\
\text { RES }\end{array}$ & $\begin{array}{l}80 \% \\
\text { base }\end{array}$ & $\begin{array}{c}80 \% \\
\text { high-bio } \\
\text { energy }\end{array}$ & $\begin{array}{l}80 \% \\
\text { RES }\end{array}$ & $\begin{array}{c}80 \% \\
\text { resilient }\end{array}$ & $\begin{array}{l}90 \% \\
\text { base }\end{array}$ & $\begin{array}{l}90 \% \\
\text { RES }\end{array}$ \\
\hline \multirow[t]{7}{*}{66} & January & 97.39 & $8,194.22$ & 409.71 & 368.74 & 204.86 & 245.83 & 163.88 & 131.11 & 139.30 & 147.50 \\
\hline & February & 89.26 & $7,733.25$ & 386.66 & 348.00 & 193.33 & 232.00 & 154.67 & 123.73 & 131.47 & 139.20 \\
\hline & March & 65.32 & $8,025.76$ & 401.29 & 361.16 & 200.64 & 240.77 & 160.52 & 128.41 & 136.44 & 144.46 \\
\hline & October & 5.95 & $4,760.21$ & 238.01 & 214.21 & 119.01 & 142.81 & 95.20 & 76.16 & 80.92 & 85.68 \\
\hline & November & 36.67 & $6,909.75$ & 345.49 & 310.94 & 172.74 & 207.29 & 138.20 & 110.56 & 117.47 & 124.38 \\
\hline & December & 12.97 & $2,537.24$ & 126.86 & 114.18 & 63.43 & 76.12 & 50.74 & 40.60 & 43.13 & 45.67 \\
\hline & Total & 307.56 & $38,160.44$ & $1,908.02$ & $1,717.22$ & 954.01 & $1,144.81$ & 763.21 & 610.57 & 648.73 & 686.89 \\
\hline \multirow[t]{7}{*}{90} & January & 79.39 & $6,910.59$ & 345.53 & 310.98 & 172.76 & 207.32 & 138.21 & 110.57 & 117.48 & 124.39 \\
\hline & February & 86.63 & $8,026.23$ & 401.31 & 361.18 & 200.66 & 240.79 & 160.52 & 128.42 & 136.45 & 144.47 \\
\hline & March & 46.78 & $7,735.23$ & 386.76 & 348.09 & 193.38 & 232.06 & 154.70 & 123.76 & 131.50 & 139.23 \\
\hline & October & 3.19 & $3,383.48$ & 169.17 & 152.26 & 84.59 & 101.50 & 67.67 & 54.14 & 57.52 & 60.90 \\
\hline & November & 20.28 & $6,652.47$ & 332.62 & 299.36 & 166.31 & 199.57 & 133.05 & 106.44 & 113.09 & 119.74 \\
\hline & December & 15.97 & $2,584.46$ & 129.22 & 116.30 & 64.61 & 77.53 & 51.69 & 41.35 & 43.94 & 46.52 \\
\hline & Total & 252.24 & $35,292.45$ & $1,764.62$ & $1,588.16$ & 882.31 & $1,058.77$ & 705.85 & 564.68 & 599.97 & 635.26 \\
\hline
\end{tabular}


Appendix D.7: Breakdown of results for 2080 under medium emission scenario

\begin{tabular}{|c|c|c|c|c|c|c|c|c|c|c|c|}
\hline \multicolumn{12}{|c|}{2080 (medium emission) } \\
\hline \multirow[b]{2}{*}{$\begin{array}{c}\text { Probability } \\
\qquad / \%\end{array}$} & \multirow[b]{2}{*}{ Month } & \multirow[b]{2}{*}{ HDD } & \multirow[b]{2}{*}{$\begin{array}{c}\text { Energy } \\
\text { consumption } \\
/ \mathbf{k W h}\end{array}$} & \multicolumn{8}{|c|}{$\mathrm{CO}_{2}$ emissions $/ \mathrm{kgCO}_{2}$} \\
\hline & & & & $\begin{array}{l}70 \% \\
\text { base }\end{array}$ & $\begin{array}{l}70 \% \\
\text { RES }\end{array}$ & $\begin{array}{l}80 \% \\
\text { base }\end{array}$ & $\begin{array}{c}80 \% \\
\text { high-bio } \\
\text { energy }\end{array}$ & $\begin{array}{l}80 \% \\
\text { RES }\end{array}$ & $\begin{array}{c}\mathbf{8 0 \%} \\
\text { resilient }\end{array}$ & $\begin{array}{l}90 \% \\
\text { base }\end{array}$ & $\begin{array}{l}90 \% \\
\text { RES }\end{array}$ \\
\hline \multirow[t]{7}{*}{10} & January & 149.55 & $9,342.96$ & 467.15 & 420.43 & 233.57 & 280.29 & 186.86 & 149.49 & 158.83 & 168.17 \\
\hline & February & 118.56 & $8,526.09$ & 426.30 & 383.67 & 213.15 & 255.78 & 170.52 & 136.42 & 144.94 & 153.47 \\
\hline & March & 74.38 & $7,833.94$ & 391.70 & 352.53 & 195.85 & 235.02 & 156.68 & 125.34 & 133.18 & 141.01 \\
\hline & October & 17.05 & $5,934.79$ & 296.74 & 267.07 & 148.37 & 178.04 & 118.70 & 94.96 & 100.89 & 106.83 \\
\hline & November & 60.59 & $7,284.88$ & 364.24 & 327.82 & 182.12 & 218.55 & 145.70 & 116.56 & 123.84 & 131.13 \\
\hline & December & 50.08 & $3,785.41$ & 189.27 & 170.34 & 94.64 & 113.56 & 75.71 & 60.57 & 64.35 & 68.14 \\
\hline & Total & 470.21 & $42,708.07$ & $2,135.40$ & $1,921.86$ & $1,067.70$ & $1,281.24$ & 854.16 & 683.33 & 726.04 & 768.75 \\
\hline \multirow[t]{7}{*}{33} & January & 130.46 & $8,710.52$ & 435.53 & 391.97 & 217.76 & 261.32 & 174.21 & 139.37 & 148.08 & 156.79 \\
\hline & February & 86.72 & $8,027.80$ & 401.39 & 361.25 & 200.69 & 240.83 & 160.56 & 128.44 & 136.47 & 144.50 \\
\hline & March & 71.04 & $7,782.21$ & 389.11 & 350.20 & 194.56 & 233.47 & 155.64 & 124.52 & 132.30 & 140.08 \\
\hline & October & 10.58 & $5,166.39$ & 258.32 & 232.49 & 129.16 & 154.99 & 103.33 & 82.66 & 87.83 & 93.00 \\
\hline & November & 49.10 & $7,771.44$ & 388.57 & 349.71 & 194.29 & 233.14 & 155.43 & 124.34 & 132.11 & 139.89 \\
\hline & December & 10.10 & $3,158.97$ & 157.95 & 142.15 & 78.97 & 94.77 & 63.18 & 50.54 & 53.70 & 56.86 \\
\hline & Total & 358.00 & $40,617.33$ & $2,030.87$ & $\mathbf{1 , 8 2 7 . 7 8}$ & $1,015.43$ & $1,218.52$ & 812.35 & 649.88 & 690.49 & 731.11 \\
\hline \multirow[t]{7}{*}{50} & January & 114.58 & $8,795.80$ & 439.79 & 395.81 & 219.89 & 263.87 & 175.92 & 140.73 & 149.53 & 158.32 \\
\hline & February & 85.42 & $8,006.18$ & 400.31 & 360.28 & 200.15 & 240.19 & 160.12 & 128.10 & 136.10 & 144.11 \\
\hline & March & 62.10 & $6,641.87$ & 332.09 & 298.88 & 166.05 & 199.26 & 132.84 & 106.27 & 112.91 & 119.55 \\
\hline & October & 5.64 & $4,088.74$ & 204.44 & 183.99 & 102.22 & 122.66 & 81.77 & 65.42 & 69.51 & 73.60 \\
\hline & November & 40.58 & $6,637.34$ & 331.87 & 298.68 & 165.93 & 199.12 & 132.75 & 106.20 & 112.83 & 119.47 \\
\hline & December & 13.53 & $2,879.46$ & 143.97 & 129.58 & 71.99 & 86.38 & 57.59 & 46.07 & 48.95 & 51.83 \\
\hline & Total & 321.85 & $37,049.38$ & $1,852.47$ & $1,667.22$ & 926.23 & $1,111.48$ & 740.99 & 592.79 & 629.84 & 666.89 \\
\hline
\end{tabular}




\begin{tabular}{|c|c|c|c|c|c|c|c|c|c|c|c|}
\hline \multicolumn{12}{|c|}{2080 (medium emission) } \\
\hline \multirow[b]{2}{*}{$\begin{array}{c}\text { Probability } \\
/ \%\end{array}$} & \multirow[b]{2}{*}{ Month } & \multirow[b]{2}{*}{ HDD } & \multirow[b]{2}{*}{$\begin{array}{c}\text { Energy } \\
\text { consumption } \\
/ \mathbf{k W h}\end{array}$} & \multicolumn{8}{|c|}{$\mathrm{CO}_{2}$ emissions $/ \mathrm{kgCO}_{2}$} \\
\hline & & & & $\begin{array}{l}70 \% \\
\text { base }\end{array}$ & $\begin{array}{l}70 \% \\
\text { RES }\end{array}$ & $\begin{array}{l}80 \% \\
\text { base }\end{array}$ & $\begin{array}{c}80 \% \\
\text { high-bio } \\
\text { energy }\end{array}$ & $\begin{array}{l}\text { 80\% } \\
\text { RES }\end{array}$ & $\begin{array}{c}\mathbf{8 0 \%} \\
\text { resilient }\end{array}$ & $\begin{array}{l}90 \% \\
\text { base }\end{array}$ & $\begin{array}{l}90 \% \\
\text { RES }\end{array}$ \\
\hline \multirow[t]{7}{*}{66} & January & 101.53 & $8,259.35$ & 412.97 & 371.67 & 206.48 & 247.78 & 165.19 & 132.15 & 140.41 & 148.67 \\
\hline & February & 69.40 & $7,756.87$ & 387.84 & 349.06 & 193.92 & 232.71 & 155.14 & 124.11 & 131.87 & 139.62 \\
\hline & March & 45.79 & $7,053.18$ & 352.66 & 317.39 & 176.33 & 211.60 & 141.06 & 112.85 & 119.90 & 126.96 \\
\hline & October & 3.80 & $3,393.10$ & 169.66 & 152.69 & 84.83 & 101.79 & 67.86 & 54.29 & 57.68 & 61.08 \\
\hline & November & 26.67 & $6,752.89$ & 337.64 & 303.88 & 168.82 & 202.59 & 135.06 & 108.05 & 114.80 & 121.55 \\
\hline & December & 36.87 & $3,578.83$ & 178.94 & 161.05 & 89.47 & 107.36 & 71.58 & 57.26 & 60.84 & 64.42 \\
\hline & Total & 284.06 & $36,794.21$ & $1,839.71$ & $1,655.74$ & 919.86 & $1,103.83$ & 735.88 & 588.71 & 625.50 & 662.30 \\
\hline \multirow[t]{7}{*}{90} & January & 73.45 & $7,486.30$ & 374.31 & 336.88 & 187.16 & 224.59 & 149.73 & 119.78 & 127.27 & 134.75 \\
\hline & February & 48.09 & $7,422.27$ & 371.11 & 334.00 & 185.56 & 222.67 & 148.45 & 118.76 & 126.18 & 133.60 \\
\hline & March & 30.36 & $7,144.21$ & 357.21 & 321.49 & 178.61 & 214.33 & 142.88 & 114.31 & 121.45 & 128.60 \\
\hline & October & 2.17 & $2,367.45$ & 118.37 & 106.54 & 59.19 & 71.02 & 47.35 & 37.88 & 40.25 & 42.61 \\
\hline & November & 14.89 & $4,567.55$ & 228.38 & 205.54 & 114.19 & 137.03 & 91.35 & 73.08 & 77.65 & 82.22 \\
\hline & December & 23.37 & $3,367.30$ & 168.37 & 151.53 & 84.18 & 101.02 & 67.35 & 53.88 & 57.24 & 60.61 \\
\hline & Total & 192.33 & $32,355.08$ & $1,617.75$ & $1,455.98$ & 808.88 & 970.65 & 647.10 & 517.68 & 550.04 & 582.39 \\
\hline
\end{tabular}


Appendix D.8: Breakdown of results for 2080 under high emission scenario

\begin{tabular}{|c|c|c|c|c|c|c|c|c|c|c|c|}
\hline \multicolumn{12}{|c|}{2080 (high emission) } \\
\hline \multirow[b]{2}{*}{$\begin{array}{c}\text { Probability } \\
/ \%\end{array}$} & \multirow[b]{2}{*}{ Month } & \multirow[b]{2}{*}{ HDD } & \multirow[b]{2}{*}{$\begin{array}{c}\text { Energy } \\
\text { consumption } \\
/ \mathbf{k W h}\end{array}$} & \multicolumn{8}{|c|}{$\mathrm{CO}_{2}$ emissions/kgCO} \\
\hline & & & & $\begin{array}{l}70 \% \\
\text { base }\end{array}$ & $\begin{array}{l}\text { 70\% } \\
\text { RES }\end{array}$ & $\begin{array}{l}80 \% \\
\text { base }\end{array}$ & $\begin{array}{c}80 \% \\
\text { high-bio } \\
\text { energy }\end{array}$ & $\begin{array}{l}\text { 80\% } \\
\text { RES }\end{array}$ & $\begin{array}{c}\mathbf{8 0 \%} \\
\text { resilient }\end{array}$ & $\begin{array}{l}90 \% \\
\text { base }\end{array}$ & $\begin{array}{l}90 \% \\
\text { RES }\end{array}$ \\
\hline \multirow[t]{7}{*}{10} & January & 146.66 & $8,961.12$ & 448.06 & 403.25 & 224.03 & 268.83 & 179.22 & 143.38 & 152.34 & 161.30 \\
\hline & February & 106.55 & $8,337.21$ & 416.86 & 375.17 & 208.43 & 250.12 & 166.74 & 133.40 & 141.73 & 150.07 \\
\hline & March & 62.36 & $7,646.06$ & 382.30 & 344.07 & 191.15 & 229.38 & 152.92 & 122.34 & 129.98 & 137.63 \\
\hline & October & 7.25 & $5,780.72$ & 289.04 & 260.13 & 144.52 & 173.42 & 115.61 & 92.49 & 98.27 & 104.05 \\
\hline & November & 48.05 & $7,754.83$ & 387.74 & 348.97 & 193.87 & 232.64 & 155.10 & 124.08 & 131.83 & 139.59 \\
\hline & December & 49.37 & $3,774.34$ & 188.72 & 169.85 & 94.36 & 113.23 & 75.49 & 60.39 & 64.16 & 67.94 \\
\hline & Total & 420.24 & $42,254.27$ & $2,112.71$ & $1,901.44$ & $1,056.36$ & $1,267.63$ & 845.09 & 676.07 & 718.32 & 760.58 \\
\hline \multirow[t]{7}{*}{33} & January & 105.79 & $7,991.78$ & 399.59 & 359.63 & 199.79 & 239.75 & 159.84 & 127.87 & 135.86 & 143.85 \\
\hline & February & 82.83 & $7,966.33$ & 398.32 & 358.48 & 199.16 & 238.99 & 159.33 & 127.46 & 135.43 & 143.39 \\
\hline & March & 57.57 & $7,571.12$ & 378.56 & 340.70 & 189.28 & 227.13 & 151.42 & 121.14 & 128.71 & 136.28 \\
\hline & October & 4.51 & $5,070.90$ & 253.55 & 228.19 & 126.77 & 152.13 & 101.42 & 81.13 & 86.21 & 91.28 \\
\hline & November & 40.21 & $7,298.93$ & 364.95 & 328.45 & 182.47 & 218.97 & 145.98 & 116.78 & 124.08 & 131.38 \\
\hline & December & 43.23 & $3,678.34$ & 183.92 & 165.53 & 91.96 & 110.35 & 73.57 & 58.85 & 62.53 & 66.21 \\
\hline & Total & 334.14 & $39,577.41$ & $1,978.87$ & $1,780.98$ & 989.44 & $1,187.32$ & 791.55 & 633.24 & 672.82 & 712.39 \\
\hline \multirow[t]{7}{*}{50} & January & 104.08 & $8,298.57$ & 414.93 & 373.44 & 207.46 & 248.96 & 165.97 & 132.78 & 141.08 & 149.37 \\
\hline & February & 60.16 & $7,611.22$ & 380.56 & 342.50 & 190.28 & 228.34 & 152.22 & 121.78 & 129.39 & 137.00 \\
\hline & March & 38.64 & $7,274.48$ & 363.72 & 327.35 & 181.86 & 218.23 & 145.49 & 116.39 & 123.67 & 130.94 \\
\hline & October & 3.82 & $3,060.09$ & 153.00 & 137.70 & 76.50 & 91.80 & 61.20 & 48.96 & 52.02 & 55.08 \\
\hline & November & 31.35 & $6,826.06$ & 341.30 & 307.17 & 170.65 & 204.78 & 136.52 & 109.22 & 116.04 & 122.87 \\
\hline & December & 31.35 & $3,492.31$ & 174.62 & 157.15 & 87.31 & 104.77 & 69.85 & 55.88 & 59.37 & 62.86 \\
\hline & Total & 269.40 & $36,562.73$ & $1,828.14$ & $1,645.32$ & 914.07 & $1,096.88$ & 731.25 & 585.00 & 621.57 & 658.13 \\
\hline
\end{tabular}




\begin{tabular}{|c|c|c|c|c|c|c|c|c|c|c|c|}
\hline \multicolumn{12}{|c|}{2080 (high emission) } \\
\hline \multirow[b]{2}{*}{$\begin{array}{c}\text { Probability } \\
/ \%\end{array}$} & \multirow[b]{2}{*}{ Month } & \multirow[b]{2}{*}{ HDD } & \multirow[b]{2}{*}{$\begin{array}{c}\text { Energy } \\
\text { consumption } \\
/ \mathbf{k W h}\end{array}$} & \multicolumn{8}{|c|}{$\mathrm{CO}_{2}$ emissions/kgCO} \\
\hline & & & & $\begin{array}{l}70 \% \\
\text { base }\end{array}$ & $\begin{array}{l}70 \% \\
\text { RES }\end{array}$ & $\begin{array}{l}80 \% \\
\text { base }\end{array}$ & $\begin{array}{c}80 \% \\
\text { high-bio } \\
\text { energy }\end{array}$ & $\begin{array}{l}\text { 80\% } \\
\text { RES }\end{array}$ & $\begin{array}{c}80 \% \\
\text { resilient }\end{array}$ & $\begin{array}{l}90 \% \\
\text { base }\end{array}$ & $\begin{array}{l}90 \% \\
\text { RES }\end{array}$ \\
\hline \multirow[t]{7}{*}{66} & January & 85.49 & $8,007.80$ & 400.39 & 360.35 & 200.19 & 240.23 & 160.16 & 128.12 & 136.13 & 144.14 \\
\hline & February & 55.21 & $7,200.75$ & 360.04 & 324.03 & 180.02 & 216.02 & 144.01 & 115.21 & 122.41 & 129.61 \\
\hline & March & 37.21 & $6,918.32$ & 345.92 & 311.32 & 172.96 & 207.55 & 138.37 & 110.69 & 117.61 & 124.53 \\
\hline & October & 2.81 & $3,377.50$ & 168.87 & 151.99 & 84.44 & 101.32 & 67.55 & 54.04 & 57.42 & 60.79 \\
\hline & November & 23.59 & $6,370.89$ & 318.54 & 286.69 & 159.27 & 191.13 & 127.42 & 101.93 & 108.31 & 114.68 \\
\hline & December & 30.29 & $3,476.22$ & 173.81 & 156.43 & 86.91 & 104.29 & 69.52 & 55.62 & 59.10 & 62.57 \\
\hline & Total & 234.60 & $35,351.47$ & $1,767.57$ & $\mathbf{1 , 5 9 0 . 8 2}$ & 883.79 & $\mathbf{1 , 0 6 0 . 5 4}$ & 707.03 & 565.62 & 600.98 & 636.33 \\
\hline \multirow[t]{7}{*}{90} & January & 52.88 & $7,163.54$ & 358.18 & 322.36 & 179.09 & 214.91 & 143.27 & 114.62 & 121.78 & 128.94 \\
\hline & February & 41.73 & $6,988.52$ & 349.43 & 314.48 & 174.71 & 209.66 & 139.77 & 111.82 & 118.80 & 125.79 \\
\hline & March & 17.56 & $6,609.70$ & 330.48 & 297.44 & 165.24 & 198.29 & 132.19 & 105.76 & 112.36 & 118.97 \\
\hline & October & 0.83 & $1,013.05$ & 50.65 & 45.59 & 25.33 & 30.39 & 20.26 & 16.21 & 17.22 & 18.23 \\
\hline & November & 12.78 & $4,201.08$ & 210.05 & 189.05 & 105.03 & 126.03 & 84.02 & 67.22 & 71.42 & 75.62 \\
\hline & December & 14.87 & $3,233.79$ & 161.69 & 145.52 & 80.84 & 97.01 & 64.68 & 51.74 & 54.97 & 58.21 \\
\hline & Total & 140.65 & $29,209.68$ & $1,460.48$ & $1,314.44$ & 730.24 & 876.29 & 584.19 & 467.35 & 496.56 & 525.77 \\
\hline
\end{tabular}

